NBER WORKING PAPER SERIES

FRAMING EFFECTS AND EXPECTED SOCIAL SECURITY CLAIMING BEHAVIOR

\author{
Jeffrey R. Brown \\ Arie Kapteyn \\ Olivia S. Mitchell \\ Working Paper 17018 \\ http://www.nber.org/papers/w17018
}

\author{
NATIONAL BUREAU OF ECONOMIC RESEARCH \\ 1050 Massachusetts Avenue \\ Cambridge, MA 02138
}

May 2011

The research reported herein was performed pursuant to a grant from the U.S. Social Security Administration (SSA) funded as part of the Financial Literacy Consortium. The authors also acknowledge support provided by the Pension Research Council and Boettner Center at the Wharton School of the University of Pennsylvania, and the RAND Corporation. The authors thank Mary Fu for her expert research assistance, and Matthew Greenwald, Tania Gutsche, Lisa Marinelli, Lisa Schneider, and Bas Weerman for their invaluable comments and assistance on the project. We also thank Steve Goss and Steve McKay of SSA for their guidance. The opinions and conclusions expressed herein are solely those of the authors and do not represent the opinions or policy of SSA, any agency of the Federal Government, the National Bureau of Economic Research, or any other institution with which the authors are affiliated.

NBER working papers are circulated for discussion and comment purposes. They have not been peerreviewed or been subject to the review by the NBER Board of Directors that accompanies official NBER publications.

(C) 2011 by Jeffrey R. Brown, Arie Kapteyn, and Olivia S. Mitchell. All rights reserved. Short sections of text, not to exceed two paragraphs, may be quoted without explicit permission provided that full credit, including $\odot$ notice, is given to the source. 
Framing Effects and Expected Social Security Claiming Behavior

Jeffrey R. Brown, Arie Kapteyn, and Olivia S. Mitchell

NBER Working Paper No. 17018

May 2011

JEL No. D03,D12,D14,H55

\begin{abstract}
$\underline{\text { ABSTRACT }}$
Eligible participants in the U.S. Social Security system may claim benefits anytime from age 62-70, with benefit levels actuarially adjusted based on the claiming age. This paper shows that individual intentions with regard to Social Security claiming ages are sensitive to how the early versus late claiming decision is framed. Using an experimental design, we find that the use of a "break-even analysis" has the very strong effect of encouraging individuals to claim early. We also show that individuals are more likely to report they will delay claiming when later claiming is framed as a gain, and when the information provides an anchoring point at older, rather than younger, ages. Moreover, females, individuals with credit card debt, and workers with lower expected benefits are more strongly influenced by framing. We conclude that some individuals may not make fully rational optimizing choices when it comes to choosing a claiming date.
\end{abstract}

Jeffrey R. Brown

Department of Finance

University of Illinois at Urbana-Champaign

515 East Gregory Drive

Champaign, IL 61820

and NBER

brownjr@illinois.edu
Olivia S. Mitchell

University of Pennsylvania

Wharton School

3620 Locust Walk, St 3000 SH-DH

Philadelphia, PA 19104-6302

and NBER

mitchelo@wharton.upenn.edu

Arie Kapteyn

RAND Corporation

1776 Main Street

P.O. Box 2138

Santa Monica, CA 90407-2138

arie_kapteyn@rand.org 


\title{
Framing Effects and Expected Social Security Claiming Behavior
}

\author{
Jeffrey R. Brown, Arie Kapteyn, and Olivia S. Mitchell
}

\section{Introduction}

In the years since prospect theory first emerged onto the scene, economists have come to understand that important economic decisions can be substantially altered by the way in which information is framed. Perhaps the best-known example was offered by Tversky and Kahneman (1981), who showed that presenting a public policy choice in terms of "lives saved" versus "lives lost” dramatically shifted the proportion of the respondents who supported a given policy. More generally, numerous experimental and real-world settings indicate that individuals make decisions based not only on their consequences or outcomes - as would be predicted by traditional economic theory - but also based on how the choices are framed.

Whereas a large literature has applied other insights from behavioral economics to retirement and savings behavior (e.g., the influential work on automatic enrollment in retirement plans by Madrian and Shea, 2001), researchers have only recently begun to explore the role of framing in influencing important decisions related to retirement. Brown et al. (2008) show that when financial products are presented in a frame that emphasizes consumption features, life annuities are perceived to be more attractive than non-annuitized assets. In contrast, when such products are presented in an investment-oriented frame, the majority of respondents prefer the non-annuitized alternative. Agnew et al. (2008) also find that framing which highlights the illiquidity aspect of annuitization makes individuals less likely to elect annuities. ${ }^{1}$

\footnotetext{
1 There is, of course, a rich literature on how framing influences a wide range of economic decisions including Andreoni (1995), Bateman et al. (1997), and Shafir et al. (1997), among many others.
} 
In this paper, we test whether framing can influence an important financial decision that approximately $93 \%$ of all Americans will make as they enter into retirement: ${ }^{2}$ when to claim Social Security benefits. In the U.S. Social Security system, eligible individuals are entitled to claim benefits as early as age 62, but they can also defer the age at which they claim to as late as age 70. Monthly benefit levels are adjusted for one’s claiming age, and these adjustments can be substantial: for example, an individual who stops working at age 62 but waits to claim benefits at age 70 will receive $76 \%$ more (real) dollars per month for the rest of her life, than if she claimed benefits at age 62. This adjustment is said to be "actuarially fair," in that the expected presented value of the two streams of benefits will be equal for individuals with average population mortality. ${ }^{3}$

Though the two benefit streams are designed to be equal in expected present value for the average individual, they generally are not equivalent when viewed through an expected utility framework. Heterogeneity of economic circumstances and/or preferences can lead to different optimal claiming ages for different individuals (e.g., Coile et al. 2002; Hurd et al. 2004). For example, liquidity-constrained individuals with a high disutility of labor and above-average expected mortality rates may find it optimal to claim early. In contrast, risk-averse consumers with non-annuitized financial wealth may find it optimal to delay claiming because delayed claiming is effectively akin to purchasing additional amounts of inflation-indexed annuitized income that will last for life, which the literature on annuities suggest would be welfare-

\footnotetext{
${ }^{2}$ According to the Social Security Administration, 93\% of all U.S. workers in 2010 were covered under the U.S. Social Security system. (http://www.ssa.gov/pressoffice/basicfact.htm)

${ }^{3}$ This paper abstracts from the question of whether additional years of work would change future benefits, as well as the question of how delayed claiming might influence spousal and survivor benefits. This is because we are focused here only on how individual claiming might vary with different frames. In a recent survey, $75 \%$ of respondents indicated that they understand that benefits need not be claimed at the time they stop work (Greenwald et al. 2010b).
} 
enhancing for many. ${ }^{4}$ Indeed, the large literature on the "annuity puzzle" suggests that at least some part of the population is under-annuitized, and the limited extent to which people delay benefits claiming is one part of that puzzle.

Rather than assuming that the choice of one's claiming date is a purely rational outcomes-based decision, we posit that individuals may be sensitive to the manner in which claiming information is framed. To study this, we have devised an experiment which presents individuals with alternative information formats about how benefits would be adjusted if they were to claim benefits early versus later. These alternative frames are shown to participants in the RAND American Life Panel (ALP), an internet-based survey. ${ }^{5}$ Panel participants were randomized into one of 10 groups, and members of each group were presented the same underlying claiming information but in different frames. It is important to emphasize that the underlying financial information provided to participants - namely, the monthly benefit they would receive at alternative ages - was unaffected by the frame: only how this information was presented was altered. We then asked the participants at what age they would claim benefits given each frame, and we compare results to determine if the frame seems to alter anticipated claiming ages.

The first of the ten frames we designed serves as a baseline by depicting the information as neutrally as possible. This frame is similar to the approach currently (since 2008) used by the Social Security Administration in its public information on claiming. The second frame emphasizes a "breakeven” concept, i.e., it emphasizes the minimum number of years one would need to live, in order for the nominal sum of the incremental monthly payments that arise from

\footnotetext{
${ }^{4}$ The annuity literature is lengthy and rich, beginning with Yaari (1965), including important work by Friedman and Warshawsky (1990) and Eckstein et al (1985) and recently including Davidoff et al. (2005) and Horneff et al. (2007, 2009).

${ }^{5}$ https://mmicdata.rand.org/alp/index.php/Main_Page
} 
delay to offset the income forgone during the period of delay. This approach essentially frames the decision as a risky gamble while downplaying insurance aspects of the choice. This breakeven approach is consistent with how Social Security field representatives presented this choice to potential claimants for many decades (at least until 2008 when they switched to a more neutral frame). This approach is also widely used in the private sector financial advice and planning industry (c.f., Charles Schwab, 2010; GG\&G 2011).

The remaining eight frames show respondents combinations of differences along three dimensions: (i) consumption versus investment; (ii) gains versus losses; and (iii) older versus younger reference ages. The first of these is motivated by the work of Brown et al. (2008) where they found important differences in the reported attractiveness of life annuities, depending on whether these were described using "consumption language" or "investment language." The second dimension uses "gain" versus "loss" terminology to portray the actuarial adjustment for later versus earlier claiming. The third dimension varies the initial age used to anchor individuals in the presentation.

In all frames, respondents are provided with a sliding scale showing monthly benefit amounts at all ages between 62 and 70 (in monthly increments). The individual can use a computer mouse to slide along the scale and watch the benefits change with each claiming age. The initial starting point for the claim age indicator matches the reference age provided in each frame. After viewing a frame, individuals are asked to use the sliding scale to pinpoint the age at which they think they are most likely to claim benefits. (Screen shots of the frames and the slider are presented in Appendix A).

We find several important differences across frames. The single largest effect is that using the breakeven analysis leads to substantially earlier expected claiming dates than any of 
the other nine frames. For example, exposure to the breakeven frame leads people to report an expected claiming age that is 12-15 months earlier (depending on specification) than under the baseline frame. The magnitude of this result is quite large compared to prior estimates of how changes in economic variables influence retirement dates. ${ }^{6}$

Smaller, but still significant, differences obtain across other frames. Overall, joint tests indicate that presentation of gains leads to later claiming than losses. We also find evidence of an "anchoring" effect with regard to age. For example, we find that showing respondents a later age from which they can then evaluate benefit changes tends to have the effect of getting them to claim later. We find that presenting respondents with a consumption gain frame anchored at age 66 yields the highest claiming age, though several others also generate significantly later claiming ages than the neutral frame (e.g. the investment gain frame with anchoring at 66, and both the consumption loss and investment loss frame at 70.)

These findings are important for our understanding of economic behavior and also for practical policy purposes. At an academic level, we provide further evidence that even highvisibility, high-stakes financial decisions - in this case, when to claim Social Security benefits are sensitive to how the information is presented. One interpretation of our results is that they cast doubt on a simple economic model of fully rational decision-making by showing that individual decisions are influenced by factors other than ultimate consumption outcomes. At a practical policy level, our study indicates that the Social Security Administration (SSA), as well

\footnotetext{
${ }^{6}$ For example, Coronado and Perozek (2003) find that each additional $\$ 100,000$ of unexpected gains from stocks is associated with retiring only two weeks earlier than expected. Lumsdaine and Mitchell (1999) review the literature on the economic determinants of retirement behavior and conclude that changes in pension and Social Security benefits have small economic impacts on the choice of retirement age, as do Gustman and Steinmeier (2004; 2008). The present analysis focuses on Social Security benefit claiming decisions, as distinct from retirement decisions, and one might expect the claiming elasticity to be larger than the retirement elasticity. A few analysts (Benitez-Silva and Frank, 2008; Honig and Reimers 1996) examine interactions between claiming and work patterns, but they are interested in rewards to continued employment, whereas here we explore determinants of the claiming decision independent of the return-to-work decision.
} 
as other public or private sector actors, can present information to participants in ways that can strongly influence behavior -- even when the actual information content is unchanged. This is particularly relevant for an agency such as the SSA that prides itself on providing relevant information without providing advice. Our findings suggest that individuals are very likely to adjust their claiming behavior, depending on how the information is presented.

In what follows, Section II provides a very brief primer on how Social Security benefit claiming works, including a discussion of the actuarial adjustment process. In Section III, we discuss our research methodology including details about the RAND American Life Panel. In Section IV, we explain the motivation underlying our choice of the 10 frames that we tested. Results are discussed in Section V, and we provide a short conclusion in Section VI.

\section{Social Security Benefits and Claiming}

How Social Security benefits are adjusted based on the claiming date

A covered worker who has contributed to the Social Security system for sufficiently long (roughly 10 years to be fully insured) ${ }^{7}$ confronts a range of choices regarding when he can file for, or claim, his Social Security benefits. Age 62 is the earliest that one can claim as a retired worker, and this is also known as the Early Retirement Age (ERA). The rules also specify a Normal Retirement Age (NRA) ${ }^{8}$ at which "full” or unreduced benefits can be paid. The NRA is currently age 66 (for those born 1943-54, rising to 67 for people born 1960 and later).

\footnotetext{
${ }^{7}$ Technically, an individual is considered fully insured once he has earned 40 "quarters of coverage. In 2010, an individual earns a quarter of coverage - up to a maximum of 4 per calendar year - for each $\$ 1,120$ of covered earnings. See http://www.ssa.gov/OACT/COLA/QC.html for more information.

${ }^{8}$ This is also sometimes referred to as the Full Retirement Age (FRA)
} 
The SSA computes benefits by selecting a worker's highest 35 years of earnings and wage-indexing them so that nominal earnings are adjusted to "near-current wage levels."9 Next, the agency computes the worker's Average Indexed Monthly Earnings (AIME) over the 35-year period by averaging all indexed annual values (including zeros, if any) and dividing by 12 . Then the basic benefit or Primary Insurance Amount (PIA) is computed as a nonlinear function of the worker's AIME; this is the base amount from which benefits are calculated. If the worker claims benefits at the NRA, his benefit equals $100 \%$ of his PIA. However, if he claims at some younger age, his benefit amount is reduced by $5 / 9$ percent per month for the first 36 months of early benefit receipt and 5/12 percent per month for additional months of early claiming, and the reduction continues for the rest of his life (Frolik and Kaplan, 2010). For instance, at age 62 he would receive a PIA reduced by $25 \% .{ }^{10}$ Conversely, if he were to leave work but delay claiming beyond the NRA, his benefits are increased by $8 \%$ per year of age beyond the NRA for the remainder of his life; this is the Delayed Retirement Credit (DRC). ${ }^{11}$ In other words, the age one stops working need not equal the age at which one claims benefits. ${ }^{12}$

The intent of the early retirement reduction and delayed retirement credit adjustments is to recognize, on average, early claimants will receive benefits for a longer period than those who delay claiming. These adjustments therefore seek to be roughly actuarially neutral, so that, on average, people who take a lower benefit early would expect to receive about the same total amount in benefits over their lifetimes, compared to those who wait for the higher monthly benefit but start receiving it later. In other words, the choice of claiming age affects the monthly

9 This is computed as the year in which a worker turns age 60; for more information, see http://www.ssa.gov/OACT/ProgData/retirebenefit1.html

${ }^{10}$ Taken from http://www.ssa.gov/OACT/quickcalc/earlyretire.html. Benefits payable to spouses and survivors are also adjusted based on the covered worker's claiming age, but we abstract from this in the present study (for more discussion see Coile et al. 2002 and Mahaney and Carlson 2008).

${ }^{11}$ In addition, Social Security benefits are annually adjusted for cost-of-living.

${ }^{12}$ This difference is widely appreciated; see Greenwald et al. (2010). In practice, the majority of workers (over 90\%) claim when first eligible at age 62; see Hurd and Rohwedder (2004) and Coile et al. (2002). 
annuity stream, but for the population on average, it does not alter the expected total lifetime sum of benefits received.

\section{Other Factors Influencing the Claiming Decision}

The prior discussion of the effect of claiming age on benefits, while accurate, is a simplification of the broader claiming decision. In reality, there are a number of complex factors that go into the consideration of an optimal claiming date. In particular, this paper is focused specifically on the claiming decision, rather than the broader impact of benefit amounts on labor force participation. Technically, the claiming decision is fully independent of one's labor force participation status: people need not claim upon leaving the labor force, and they need not leave employment to claim. In practice, of course, there are obvious connections between retirement and Social Security claiming decisions. For example, if individuals continue to work while delaying claiming, their monthly benefit may rise both because of the actuarial adjustment and because of the additional years of earnings potentially increasing their PIAs. Additionally, lowwealth, liquidity-constrained individuals may not have the resources to provide for their consumption after retirement if they do not claim Social Security, and thus the claiming decision may be tightly linked with broader labor force participation considerations.

Another reason that labor force participation and claiming are intertwined in practice is the Social Security "earnings test." As described by the Social Security Administration, if one continues to work after claiming benefits, and if one is younger than the Normal Retirement Age, “\$1 in benefits will be deducted for each $\$ 2$ you earn above the annual limit."13 Importantly, the reduction in benefits that results from the application of the earnings test is returned to the

\footnotetext{
${ }^{13}$ http://ssa-custhelp.ssa.gov/app/answers/detail/a_id/236/ /effects-of-working-and-receiving-social-securityretirement-benefits. For 2010, the annual limit is $\$ 14,160$. In the year one reaches the normal retirement age, the reduction is $\$ 1$ for every $\$ 3$ above a higher limit, up until the month one reaches the NRA. .
} 
beneficiary in the form of higher future benefits, although it is unclear how widely this feature is understood by those affected. ${ }^{14}$

While each of these factors - and others - is quite important to consider when evaluating an optimal retirement age, we abstract from these additional considerations in our experimental design. Doing so has a distinct advantage of keeping the experimental frames as clean and simple as possible. Equally importantly, this simplification does not present a problem for our analysis, for reasons that we will describe in more detail in the next section.

\section{III.Study Design}

\section{Focus Groups}

Prior to launching our quantitative survey, we conducted a large number of focus groups in the Chicago, Los Angeles, Philadelphia, and Washington, D.C. areas. These focus groups served two distinct purposes. The first, and the one most relevant to this paper, is that we used these groups to ensure that the language used in the frames ultimately tested in the online survey (discussed in Section IV below) was clear and salient to the participants. Indeed, the focus groups were quite useful in this regard, and they helped us to develop frames that respondents considered distinct along the margins that we wished to test, while maintaining their symmetry along other dimensions. The second purpose of the focus groups was to gain an understanding of a broader set of issues related to how individuals view the role of Social Security in retirement. ${ }^{15}$ The American Life Panel

\footnotetext{
${ }^{14}$ We also abstract from the possibility that an insured individual's claiming decision may affect the after-tax maximum family benefit received by the entire household.

${ }^{15}$ While those findings are not discussed in the present paper, interested readers may find a summary of the qualitative findings in Greenwald \& Associates (2010a).
} 
After testing our frames (discussed in more detail in Section IV, below), we fielded a survey through the RAND American Life Panel (ALP). The ALP is a sample of approximately 3,000 households who are regularly interviewed over the Internet. An advantage relative to most other Internet panels is that the ALP is mostly based on a probability sample of the US population. $^{16}$ Currently, the panel comprises over 3000 active panel members of whom approximately $5 \%$ respond to the questionnaires using a WebTV. ${ }^{17}$

\section{Experimental Design}

The experimental design consists of several separate waves of data collection. We initiated the survey with a "pre-wave" in June of 2010, in which respondents were asked a single question about when they expected to claim Social Security:

\footnotetext{
${ }^{16}$ ALP respondents have been recruited in one of three ways. Most were recruited from individuals age $18+$ who were respondents to the Monthly Survey (MS) of the University of Michigan's Survey Research Center (SRC). The MS is the leading consumer sentiment survey that incorporates the long-standing Survey of Consumer Attitudes and produces, among others, the widely used Index of Consumer Expectations. Each month, the MS interviews approximately 500 households, of which 300 households are a random-digit-dial (RDD) sample and 200 are reinterviewed from the RDD sample surveyed six months previously. Until August 2008, SRC screened MS respondents by asking them if they would be willing to participate in a long term research project (with approximate response categories "no, certainly not," "probably not," "maybe," "probably," "yes, definitely"). If the response category is not "no, certainly not," respondents were told that the University of Michigan is undertaking a joint project with RAND. They were asked if they would object to SRC sharing their information about them with RAND so that they could be contacted later and asked if they would be willing to actually participate in an Internet survey. Respondents who do not have Internet were told that RAND will provide them with free Internet. Many MSrespondents are interviewed twice. At the end of the second interview, an attempt was made to convert respondents who refused in the first round. This attempt includes the mention of the fact that participation in follow-up research carries a reward of $\$ 20$ for each half-hour interview. A subset of respondents (approximately 500) was recruited through a snowball sample; here respondents were given the opportunity to suggest friends or acquaintances who might also want to participate. Those friends were then contacted and asked if they wanted to participate. A new group of respondents (approximately 500) has recently been recruited after participating in the National Survey Project, created at Stanford University with SRBI. This sample was recruited in person, and at the end of their oneyear participation, they were asked whether they were interested in joining the RAND American Life Panel. Most of these respondents were given a laptop and broadband Internet access. Recently, the American Life Panel has begun recruiting based on a random mail and telephone sample using the Dillman method (see e.g. Dillman et al, 2008) with the goal to achieve 5000 active panel members, including a 1000 Spanish language subsample. If these new participants do not have Internet access yet, they will also be provided with a laptop and broadband Internet access. These panel members are not part of the sample used in this paper.

${ }^{17}$ Respondents from the Michigan monthly survey without Internet were provided with so-called WebTVs (http://www.webtv.com/pc/), which allows them to access the Internet using their television and a telephone line. The technology allows respondents who lacked Internet access to participate in the panel and furthermore use the WebTVs for browsing the Internet or email.
} 
"We would next like to ask you a question about a different topic. As you know, in the United States people can start claiming Social Security benefits between the ages of 62 and 70. At what age would you expect to start collecting these Social Security benefits?”

This question was asked to provide a baseline which we could then compare against responses to future frames, and also to help us evaluate whether our frame randomization which occurred thereafter was not biased with regard to the outcome of interest. ${ }^{18}$

As is described in detail in Section IV below, we test 10 different question frames. In three waves spaced at least two weeks apart, respondents are shown six different frames (two distinct frames per wave). These frames are randomly assigned in the following way: for each respondent we drew six numbers randomly without replacement from the set $\{1,2, \ldots 10\}$. These numbers determined which frames were shown to each respondent and in which order. For example, if we drew the vector $(5,7,3,9,10,6)$ for a given respondent, then that respondent is shown frames 5 and 7 in the first wave, frames 3 and 9 in the second wave, and frames 10 and 6 in the third wave. The frames are only shown to respondents who had not already claimed a benefit and who have worked at least 10 years (so that we can compute a projected Social Security benefit).

Our outcome of interest is the respondent's intended claiming age. This raises a natural question of whether expectations about claiming are correlated with subsequent claiming behavior. Evidence from the Health and Retirement Survey (HRS) suggests that this is, indeed, the case: for many years the HRS has asked respondents about each person's expected claiming age every wave, making it possible to correlate these responses with ultimate claiming behavior. For HRS respondents age 62-70, we calculate the simple correlation between an indicator of

\footnotetext{
${ }^{18}$ While most respondents (95\%) provided an answer in the age 62-70 range, some did not. When respondents did not answer in this age range, a follow-up question asked why not. Responses outside the 62-70 interval were often given by younger respondents who believe that, by the time they will be eligible, the Social Security claiming age will have moved to higher ages, or they believe they will not receive any Social Security benefit at all and express this by responding outside the range.
} 
whether the individual is receiving benefits in a given wave, and an indicator for whether the individual predicted that that he or she would be claiming benefits by this wave, based on interview responses in prior waves. These two variables are strongly and positively correlated, with coefficients ranging from 0.46 in wave 1 to over 0.6 in waves 6-7. Linear probability models of benefit receipt in wave 8 on predictions of prior waves have an R-squared of about $0.6 .^{19}$

\section{The Frames}

In what follows, we explain the rationale for the choice of our experimental frames, as well as our expectations about how alternative framing would affect the claiming decision. (The actual text of frames tested appears in Appendix A.)

Our baseline case is intended to be an approximation of Social Security's current "neutral” stance on claiming ages. This is differentiated from what we call here the "breakeven" approach, which was used by SSA for many decades and which continues to be used by many financial advisors in the private sector. Next we discuss the three dimensions along which we vary our experimental frames, including: (i) the use of consumption language versus investment language, (ii) framing actuarial adjustments for earlier and later claiming as gains versus losses, and (iii) the use of alternative anchoring ages (including ages 62, 66 and 70).

a. Baseline Case: Symmetric Treatment of Gains and Losses (Anchored at Age 66)

Our baseline case is modeled on the Social Security Administration's current approach (in use since 2008) to discussing claiming ages (although we have simplified and shortened the presentation considerably for survey purposes). In essence, this approach seeks to simply and clearly lay out "the facts" in a neutral manner, with a symmetric treatment of earlier and later

\footnotetext{
${ }^{19}$ Further results available on request to the authors.
} 
claiming. This approach is consistent with the SSA's emphasis on providing information but not advice to participants, in that it seeks to avoid biasing individuals in any particular direction. Rather, it simply states the impact on benefits of claiming at various ages. Because this frame is intended to be neutral, and because it reflects the current public perspective of SSA on claiming ages, we use this frame as the baseline against which other frames are compared.

\section{b. “Breakeven Analysis” (Anchored at Age 62)}

Previous to 2008, one of the tools used by the SSA when providing information on the impact of claiming at various ages was to use a so-called "breakeven" analysis. Under this approach, individuals were told what their benefits would be if they claimed at an early age such as 62, versus at some later age, such as 63. They were then informed that, by delaying claiming from 62 to 63, they would "forfeit" a year of benefits. ${ }^{20}$ In return for the deferral, they would receive a higher monthly benefit from age 63 on. But the breakeven presentation emphasized that people would not "come out ahead" unless they lived until at least to age X, where X was defined as the age at which the cumulative benefit payment amounts were equal. This approach combines some elements of both the negative annuity framing explored by Agnew et al. (2008) and the investment frame explored by Brown et al. (2008), both of which have been shown to reduce the perceived desirability of annuitization.

While this breakeven analysis may have been instructive to many, it is also true that the framing of this approach implicitly places zero value on the insurance aspect of delaying

\footnotetext{
${ }^{20}$ SSA field offices have long been equipped with a software program that claims representatives can use to compute breakeven dates for individuals who inquired about how benefits changed with the claiming date (known by SSA as "month of election," or MOEL). Numerous conversations we have held with SSA field office representatives suggest that this breakeven analysis was widely used prior to 2008. Indeed, the use of the breakeven analysis was codified in the training manuals for employees: as recently as 2007, the training manual for Title II Claims Representatives (i.e., SSA employees who help citizens claim benefits, among other responsibilities) included a discussion of documentation required for "Month of Election" cases. It states "if the claimant chooses the later of the two possible MOELs, he will forfeit the benefits he could have received with the earlier MOEL" (emphasis added).
} 
claiming. In essence, it provides a simplistic financial calculation which emphasizes that later claimers would be "behind," until they reach a far distant breakeven date. As a result, this approach places little emphasis on the additional value that individuals who defer could receive for the rest of their lives beyond the breakeven date. This practice is akin to considering only the actuarial aspect of the decision, without taking into account the broader utility rewards of an annuity, which arise from risk aversion and protection against longevity risk. Indeed, in direct contrast to highlighting the insurance aspects of Social Security, this approach frames the decision to delay claiming more as a gamble, the outcome of which depends upon when one dies.

It is worth noting that this breakeven approach is not unique to the Social Security Administration; in fact a widely referenced article by the Schwab Center for Financial Research $(2010)^{21}$ also discusses the claiming decision using a breakeven analysis. Our hypothesis is that this breakeven approach is likely to bias individuals toward claiming benefits earlier, than would a more neutrally worded frame.

\section{c. Consumption versus Investment}

As noted earlier, a prior study by Brown et al. (2008) showed that how individuals view the value of life annuities relative to other financial products depends on whether annuities are presented in a "consumption frame" or an "investment frame." That is, when consumers are conditioned to think in terms of investments (e.g., when the presentation uses investment terminology such as "invest” and "return"), the life annuities are made to appear unattractive. This is because life annuities are then perceived as paying low returns, being illiquid, and possibly even seeming "risky" (because the amount an annuitant gets back depends on how long

\footnotetext{
${ }^{21}$ For further information see http://www.schwab.com/public/schwab/research_strategies/market_insight/retirement_strategies/planning/when_sho uld_you_take_social_security.html
} 
he lives). By contrast, in a consumption frame (e.g., a frame that emphasizes one's ability to consume throughout life), a life annuity tends to be viewed as a very attractive form of protection against running out of money.

While Brown et al. (2008) found powerful effects of framing on the attractiveness of life annuities relative to non-annuitized products, that analysis did not provide evidence on whether these alternative frames also have an effect on the desirability of "earlier" versus "later" annuitization. But given the magnitude of the effects they found (roughly $70 \%$ of respondents preferring a life annuity to a savings account in a consumption frame, versus about $20 \%$ in an investment frame), this distinction is potentially quite important to the Social Security claiming context. It is worth noting that the breakeven frame is itself a quite negative form of an investment frame, one that emphasizes the risk of not living long enough to recoup the foregone benefits. The investment language used in these additional frames focuses on "returns," without explicitly pointing out the "risk" of not breaking even. This will allow us to determine whether it is the breakeven analysis per se, or the investment-oriented language more generally, that influences claiming behavior.

\section{d. Gains versus Losses}

The asymmetry in how individuals treat gains versus losses is one of the best-known results (at least among economists) from the psychology literature on choice. Most prominently, Kahneman and Tversky (1981) found that individuals exhibited an asymmetry between gains and losses. Specifically, they found in a situation of choice under uncertainty that people sometimes exhibit a preference for a certain gain of $\$ p^{*} X$ to an uncertain gain of $\$ X$ with probability $p$, while at the same time preferring an uncertain loss of $\$ X$ with probability $p$, to a certain loss of $\$ p^{*} X$. 
Relating this to the context of benefit claiming, it is possible to express actuarial adjustments in terms of a gain (e.g., delaying claiming by one year will increase your benefit by $\$ X$ per month) or a loss (e.g., claiming one year earlier will reduce your benefit by $\$ X$ per month). Accordingly, we expect that this gain/loss distinction may have important interactions with the consumption/investment distinction. As noted by Brown et al. (2008), additional annuitization may look very attractive in a consumption frame, while it may look less attractive in an investment frame. It is also, therefore, possible that gains and losses will be interpreted differently in each of these contexts.

\section{e. Age Anchors}

As discussed at length by Mussweiler et al. (2004), “anchoring effects pervade a variety of judgments, from the trivial (i.e., estimates of the mean temperature in Antarctica) ... to the apocalyptic (i.e., estimates of the likelihood of nuclear war) ... In particular, they have been observed in a broad array of different judgmental domains, such as general-knowledge questions, price estimates, estimates of self-efficacy, probability assessments, evaluations of lotteries and gambles, legal judgment, and negotiation.”22 In our context, a very natural and salient anchoring point is the age that is first presented in each frame. Given that we are exploring both gains and losses, some variation in anchoring ages is useful. For example, while one can easily discuss gains in a frame anchored at age 62, it is not possible to anchor a loss frame at 62 because 62 is the earliest claiming age, and thus there is no way to characterize a loss from claiming earlier than this. Similarly, it is easy to anchor losses at age 70 (the maximum claiming age), but not gains. For this reason, in the experimental treatments that we describe next, the gain frames are

\footnotetext{
${ }^{22}$ We have excluded the references included in the original quote. For these, as well as a full description of findings, see: http://social-cognition.uni-koeln.de/scc4/documents/PsychPr_04.pdf.
} 
anchored at 62, and the loss frames at 70 . In order to distinguish the gain/loss hypothesis from age anchoring, we also include both gain and loss frames that are anchored at age 66 .

\section{f. The Ten Different Frames}

Putting these various permutations together results in 10 distinct frames, described more completely in the Appendix. Below we refer to these frames as follows:

(i) Baseline (neutral)

(ii) Breakeven

(iii) Consumption Gain from Age 62

(iv) Consumption Gain from Age 66

(v) Consumption Loss from Age 66

(vi) Consumption Loss from Age 70

(vii) Investment Gain from Age 62

(viii) Investment Gain from Age 66

(ix) Investment Loss from Age 66

(x) Investment Loss from Age 70

\section{g. How our Experimental Design Handles Complexity and Heterogeneity}

As discussed above, there will be heterogeneity in the optimal claiming date based on differences in economic situations as well as preferences. Heterogeneity also results from the numerous "real-life" complicating factors that would rationally influence the choice of an optimal claiming date, including labor force participation issues, the earnings test, and spousal or child benefits. Fortunately, our experimental design does not require that we know the optimal claiming date for any individual. Furthermore, our design allows us to dramatically simplify the scenarios that individuals face, including focusing on a single individual and avoiding a discussion of the earnings test.

There are three reasons that our design does not require that we specific all relevant information. First, our experimental design is premised on the idea that if an individual is making a rational optimizing decision, that optimal decision will be based on how (possibly 
unobservable) factors important to that individual map into utility outcomes. Because our framing experiment holds the relevant outcomes fixed in all cases, and only changes the way the claiming process is framed, optimizing individuals would be insensitive to frame changes. While the omission of a discussion of the earnings test, for example, might lead to answers that differ from those that the respondent would give if such information was provided, it is important to emphasize that the same information is provided or omitted in all frames, and we are examining differences across frames in how the same information is presented.

Second, we randomize individuals into the ten treatment groups. Thus, there are no concerns about self-selection based on differences in the salience of the complicating factors that we have simplified away.

Third, because we expose individuals to multiple frames, we are able to conduct some analyses including individual fixed effects, meaning that we are implicitly controlling for all unobservable differences across individuals.

In essence, our identifying assumption is that any biases introduced into the expected claiming age by our omission of some factors are independent of how the information that we are providing is framed.

\section{Results}

Table 1 presents descriptive statistics for the ALP sample used in the experiment; we also provide average expected claiming ages reported by respondents about six weeks before the start of the experiment (the June 2010 question discussed in Section III). Here and in the remainder of the paper, claiming ages are expressed in terms of the number of months after the date when 
the respondent turns 62 . Thus for example a "claiming age” of 36 means age 65 and zero months (which is 36 months after one's $62^{\text {nd }}$ birthday.)

Table 1 here

A few points are worth noting from the third column of Table 1. First, women indicate that they plan to claim Social Security benefits about four months later than men. Planned claiming ages also rise with education and income: in both cases, those in the highest category say they intend to claim benefits about 15-16 months later than the lowest category. Planned claiming ages are also slightly later for younger respondents. Thus those younger than age 50 say they plan to claim about two to four months later than respondents over age 55 . This is likely an underestimate of the population difference, since our sample is restricted to individuals not yet retired (so anyone over 55 who self-described himself as retired is not included). These summary statistics are offered for general interest, though it is worth noting that, because we randomize exposure to the frames, we would not anticipate that these baseline differences will have any impact on results across frames. Further, in specifications that include individual fixed effects, these differences will be directly controlled.

Figure 1 shows average expected claiming ages arrayed by frame across the six presentations. One can see quite clearly that the breakeven frame yields - by far - the earliest intended claiming age. There is also a suggestion of a difference between gain and loss frames, where the gain frames yield a somewhat later claiming age than the loss frames. Below we verify these results using multivariate regression models.

Figure 1 here

Table 2 presents average claiming ages for the various frames administered to the ALP broken down by treatment, and Figure 2 shows the same information in the form of a bar chart. 
Once again, the breakeven frame generates by far the lowest claiming age. For example, in wave 1.1 (the first treatment in the first wave), the breakeven frame generates a claiming age that is between 22 and 26 months earlier than the claiming age generated by the frames that take 66 as an anchoring age.

Table 2 and Figure 2 here

We are aware that there could be some "spillover" from the first to the second treatment within a wave. That is, when reading the second frame presented in a wave, the respondent might remember what he answered when shown the first frame, and possibly even offer the exact same age. Our data do indeed reveal many instances where respondents' first and second answers within a wave are identical. Below we analyze this pattern more formally. Spillovers help explain for instance why the claiming age associated with the breakeven frame is higher in 1.2 (wave 1, exposure 2), 2.2 and 3.2 than in 1.1, 2.1 and 3.1, respectively.

Table 3 and Figures 3-6 report intended claiming ages (now averaged across all waves) by frame and demographics and show that there are some differences (below we test for significance more formally). Women tend to be somewhat more responsive to the difference between gain frames and loss frames than men, deferring intended claiming ages more when benefit enhancements are emphasized. Younger people and less educated individuals appear to be more responsive to framing than older people and respondents with a college degree. The last column in Table 3 shows the variance of the average claiming ages across the ten frames, which we interpret as a measure of how sensitive respondents are to the different frames. The variance proves to be considerably larger for less-educated respondents than for respondents with a college degree, suggesting that respondents with less education are more susceptible to framing effects. The age pattern is not quite monotonic, but it does suggest more susceptibility to framing among the young versus the older respondents. 


\section{Table 3 and Figures 3-6 here}

It is useful to summarize these differences using multivariate regression analyses, with results appearing in Table 4. In all five columns, the dependent variable is the number of months after age 62 that the respondent indicates he intends to claim his Social Security benefits. The first three columns of Table 4 present results from regression analyses pertaining to the first wave. In the first two columns, we regress the number of months a respondent indicates he will claim post-62 on nine treatment dummies, one for each frame, with the omitted category being the baseline frame (which uses an anchoring age of 66 and describes the effects of changing claiming ages in symmetric terms). In the first column, the dependent variable is the answer to the first frame in the first wave (i.e. wave 1.1), while in the second column, the dependent variable is the response to the second frame in the wave (wave 1.2). As noted before, it is possible that responses to the second frame in a given wave could be influenced by responses to the first frame, so in the third column of Table 4, we use as the dependent variable the answer to the second frame exposure and also control for which frame the respondent saw in the first frame. These "lagged" dummy variables are statistically significant $(\mathrm{p}=.02)$ though a comparison of the second and third columns suggests that the estimates of the treatment effects are not much affected.

\section{Table 4 here}

When combining results across waves, it is important to account for correlations across observations that refer to the same respondents. A natural solution is to include individual fixed effects, and results are given in columns 4 and 5 of Table 4 . Accordingly, column 4 combines the results of all six waves, while column 5 once again includes dummies for preceding treatments for waves 1.2, 2.2, and 3.2. That is, when the dependent variable refers to wave 1.2, 
the treatment in wave 1.1 is included as an extra explanatory variable; similarly for wave 2.2, the treatment in 2.1 is included as an explanatory variable, and similarly for waves 3.2 and $3.1 .^{23}$

The finding of most interest in Table 4 is that several of the treatment frame coefficients differ significantly from that of the neutral frame where the anchoring age is 66. The models confirm that the breakeven SSA frame leads to substantially earlier claiming: compared to the neutral frame, the breakeven frame appears to induce claiming around 15 months earlier. This is an enormous impact, one that should be of substantial interest to policymakers who seek to offer the best unbiased advice possible to the working public.

It appears that the gain frame with anchoring at 66 yields the highest claiming age, though several others also generate significantly later claiming ages than the neutral frame specifically the loss frames with anchoring at 70 . We also note that the gain frames appear to lead to later claiming than do loss frames. The difference between the gain frames at 66 and the loss frames at 66 is statistically significant $(\mathrm{p}=.01)$.

An alternative way to disentangle the effects of anchoring ages, gain vs. loss, and consumption vs. investment, is provided in Table 5. Here we present the results of a fixed-effect analysis with the control variables now redefined to represent framing dimensions (e.g., gain versus loss, or anchoring ages) rather than individual frames. As before, the second column regression includes dummies for the preceding treatments when the dependent variable refers to waves 1.2 and 2.2. ${ }^{24}$ The joint tests reported in Table 5 show that the gain and loss frames have different effects, depending on when an individual first says he is intending to claim. That is, gain frames lead to later claiming ages than loss frames. The null hypothesis that consumption

\footnotetext{
${ }^{23}$ The coefficients on these lagged treatments are not reported, but they operate in the expected direction and are highly significant $(\mathrm{p}=.00)$.

${ }^{24}$ These "lagged treatment effects" are highly significant $(\mathrm{p}=.00)$, although the estimates in which we are most interested are very similar with or without them.
} 
and investment frames have equal effects cannot be rejected. Anchoring ages 66 and 70 are both associated with significantly later claiming ages, compared to anchoring at age 62. The difference between 66 and 70 is not significantly different from zero, however.

\section{Table 5 here}

Two additional tables permit us to test whether sub-groups of people respond differently to the manner in which benefits claiming is framed. Table 6 provides one approach, wherein we adopt the same fixed-effects model as in Table 5 but also add four additional variables, namely interaction terms between the breakeven frame and sex, the individual's predicted benefit level if he claimed at age 62, a third variable indicating whether a respondent reports having credit card debt, and a fourth variable which is a measure of financial literacy. Since the neutral frame is the reference category, one may interpret the coefficient on the interaction variables as the effect of the factor on the difference between the neutral frame and the breakeven frame.

\section{Table 6 here}

In the first column, we see that compared to men, women are prompted to claim six months earlier when they see the breakeven frame versus the neutral frame, and the effect is statistically significant. (It will be recalled that these are fixed-effects estimates, so individualspecific factors are differenced out.) The second column shows the impact of interacting respondents' anticipated monthly Social Security benefits at age 62 (the mean of that variable is $\$ 1,275)$. The statistically significant estimate implies that if the monthly benefit level were to rise from $\$ 1,275$ to $\$ 2,275$, this would narrow the gap between the neutral and the breakeven frame by 8 months. The third column shows that individuals with credit card debt are significantly more sensitive to the difference in framing between neutral and breakeven (the difference widens by about 4.5 months). One possible interpretation of this is that individuals with credit card debt 
find financial management more challenging, and are thus more affected by framing. Finally, in the fourth column we show the interaction between the financial literacy measure and the breakeven frame. The financial literacy variable simply counts the number of correct answers to a sequence of 17 financial literacy questions. ${ }^{25}$ The interaction is not statistically significant, although potentially of quantitative significance. For instance if a respondent moves from $50 \%$ correct to $100 \%$ correct, the gap between the neutral frame and breakeven narrows by 7.25 months. (The mean percent correct is 68 in the sample).

Finally, Table 7 offers a more complex set of additional interaction terms, again using a fixed-effects framework obviating the need for non-time-varying controls. Multicollinearity results from including such a large set of interactions, though the joint test of the interaction terms reported at the bottom of the table indicates that the significant differences persist by age and sex (at least at the $10 \%$ level), even in this more complex case. And the anchoring age interactions are also quite significant.

Table 7 here

\section{Conclusions}

We draw two primary conclusions, one of them of interest to academics, and the other of practical interest to policymakers and financial advisers. The academic conclusion is that individuals appear to be behaving in a manner that is inconsistent with purely rational economic optimizing behavior. Were individuals focusing solely on consumption outcomes as standard life-cycle models posit, then such decisions would be unaffected by how information is framed.

\footnotetext{
${ }^{25}$ The 17 questions measure knowledge in five domains: compound interest (4 questions), inflation (2 questions), risk diversification (3 questions), tax treatment of DC savings (4 questions), and employer matches of DC contributions (4 questions).
} 
Instead, our evidence strongly suggests that how the claiming information is framed has a substantial influence on expected claiming behavior.

The practical lesson to draw from these findings is that the manner in which information is provided to plan participants can shape behavior. Indeed this research suggests that Social Security’s historical emphasis on “breakeven analysis” may have inadvertently encouraged several generations of American workers to claim benefits earlier than they would have otherwise, had the information been presented in a different frame. It is especially important to understand these effects because - unlike the benefit rules themselves - the framing of information is under the control of the SSA staff and administration, rather than something requiring Congressional legislation to alter.

While we have provided evidence from the HRS that expected claiming ages are correlated with actual claiming ages in later waves, we nonetheless recognize that one would ideally study the effects of framing on actual claiming behavior. In principle, it is possible to experimentally test the impact of framing on actual claiming decisions, especially now that many retirement benefit claims are processed using internet-based on-line claiming. Such "real world" experiments might be a promising avenue for future analysis. 


\section{References}

Agnew, Julie, Lisa Anderson, Jeff Gerlach, and Lisa Szykman. (2008). "Who Chooses Annuities? An Experimental Investigation of Gender, Framing and Defaults." The American Economic Review, 98 (2): 418-422.

Andreoni, James. (1995). "Warm-Glow Versus Cold-Prickle: The Effects of Positive and Negative Framing on Cooperation in Experiments." Quarterly Journal of Economics, 110(1):. 121

Au, Andrew, Olivia S. Mitchell, and John W.R. Phillips. (2005). "Saving Shortfalls and Delayed Retirement.” MRRC Working Paper 2005.94

Bateman, Ian, Alistair Munro, Bruce Rhodes, Chris Starmer, Robert Sugden. (1997). “A Test of the Theory of Reference-Dependent Preferences.” Quarterly Journal of Economics, 112(2): 479505.

Benitez-Silva, Hugo, and Frank Heiland. 2008. "Early Claiming of Social Security Benefits and Labour Supply Behaviour of Older Americans." Applied Economics. 40:23.

Brown, J., J. Kling, S. Mullainathan, and M. Wrobel. (2008). "Why Don't People Insure Late Life Consumption? A Framing Explanation of the Under-Annuitization Puzzle.” The American Economic Review, 98: 304-309.

Brown, Jeffrey, Olivia S. Mitchell, and James Poterba. (2002). “The Role of Real Annuities and Indexed Bonds in an Individual Accounts Retirement Program.” In Innovations in Financing Retirement., eds. Z. Bodie, B. Hammond, and O. S. Mitchell. Philadelphia, PA: Univ. of Pennsylvania Press: 175-197.

Coile, Courtney C., Peter Diamond, Jonathan Gruber, and Alain Jousten. (2002) "Delays in Claiming Social Security Benefits.” Journal of Public Economics 84(3): 357-385.

Coronado, Julia L. and Maria G. Perozek. (2003). "Wealth Effects and the Consumption of Leisure: Retirement Decisions During the Stock Market Boom of the 1990s.” FEDS Working Paper No. 2003-20, May. Available at SSRN: http://ssrn.com/abstract=419721 or doi:10.2139/ssrn.419721.

Davidoff, Tom, Jeffrey Brown, and Peter Diamond. (2005). “Annuities and Individual Welfare.” American Economic Review, 95: 1573-1590.

Dillman, D.A., J.D Smyth, and L.M. Christian. (2008). Internet, Mail, and Mixed-Mode Surveys: The Tailored Design Method, $3^{\text {rd }}$ edition. Hoboken, NJ: Wiley.

Eckstein, Zvi , Martin S. Eichenbaum, Dan Peled. (1985). "The Distribution of Wealth and Welfare in the Presence of Incomplete Annuity Markets.” Quarterly Journal of Economics 100(3): 789-806 
Friedman, Benjamin, and Mark Warshawsky (1990). “The Cost of Annuities: Implications for Saving Behavior and Bequests.” Quarterly Journal of Economics, 105(1): 135-154

Frolik, Lawrence A. and Richard L. Kaplan. (2010) Elder Law in a Nutshell. $5^{\text {th }}$ edition. St Paul, MN: West Publishing. p. 292.

Gray, Gray \& Gray (GG\&G) (2011). “The Effect of When you Start Collecting Social Security.” http://www.gggcpas.com/tools/gggcalcs/sscal4.htm

Greenwald, Mathew \& Associates. (2010a). "Claiming Social Security Benefits and Understanding Peer Effects: A Summary Report of Ten Focus Groups.” RAND Report to the SSA for the Financial Literacy Center, September.

Greenwald, Mathew, Arie Kapteyn, Olivia S. Mitchell, and Lisa Schneider. (2010b). "What Do People Know about Social Security?” RAND Report to the FLC/SSA, September.

Gustman, Alan and Thomas L Steinmeier. (2004). “The Social Security Retirement Earnings Test, Retirement, and Benefit Claiming.” NBER Working Paper 10905, November.

Gustman, Alan and Thomas L. Steinmeier. (2008). "How Changes in Social Security Affect Retirement Trends.” NBER Working Paper 14105.

Horneff, Wolfram, Raimond Maurer, Olivia S. Mitchell, and Ivica Dus. (2007). "Following the Rules: Integrating Asset Allocation and Annuitization in Retirement Portfolios. Insurance:

Mathematics and Economics. 42: 396-408.

Horneff, Wolfram, Raimond Maurer, Olivia S. Mitchell, and Michael Stamos. (2009). "Asset Allocation and Location over the Life Cycle with Survival-Contingent Payouts." Journal of Banking and Finance, (33)9, September: 1688-1699.

Hurd, Michael, James P. Smith, Julie M. Zissimopoulos. (2004). “The Effects of Subjective Survival on Retirement and Social Security Claiming.” Journal of Applied Econometrics, 19(6): 761-775.

Kahneman, Daniel, and Amos Tversky. (1981). "The Framing of Decisions and the Psychology of Choice.” Science, 211(4481), January 30: 453-458.

Lumsdaine, Robin and Olivia S. Mitchell. (1999). "New Developments in the Economics of Retirement”. In Handbook of Labor Economics, eds. Orley Ashenfelter \& David Card. Amsterdam: North Holland: 3261-3308.

Madrian, Brigitte and Dennis F. Shea (2001)."The Power of Suggestion: Inertia in 401(k) Participation and Savings Behavior.” Quarterly Journal of Economics 116(4):1149-1187. 
Mahaney, James I. and Peter C. Carlson. (2008). "Rethinking Social Security Claiming in a 401(k) World.” In Recalibrating Retirement Spending and Saving, eds. J. Ameriks \& O.S. Mitchell. Oxford: Oxford University Press: 141-167.

Mitchell, Olivia S., James Poterba, Mark Warshawsky, and Jeffrey Brown. (1999). “New Evidence on the Money's Worth of Individual Annuities.” American Economic Review, December: 1299-1318.

Mussweiler, Thomas, Birte Englich, and Fritz Strack. (2004) “Anchoring Effect.” In Cognitive Illusions - A Handbook on Fallacies and Biases in Thinking, Judgment, and Memory, ed. R. Pohl. London: Psychology Press: 183-200.

Reimers, Cordelia, and Marjorie Honig. 1996. "Responses to Social Security by Men and Women: Myopic and Far-Sighted Behavior.” Journal of Human Resources, 31-2: 359-382.

Shafir, Eldar, Peter Diamond and Amos Tversky. (1997). “Money Illusion.” Quarterly Journal of Economics. 112(2): 341-374.

Yaari, Menachim. (1965). "Uncertain Lifetime, Life Insurance, and the Theory of the Consumer.” Review of Economic Studies, 32: 137-150. 


\section{Table 1. Descriptive Statistics on the ALP Sample}

GENDER

1 Male

2 Female

AGE

$18-40$

41-50

$51-55$

$>55$

EDUCATION

HS or less

Some college/ associate degree

College degree

HH INCOME

$<35000$

$35000-74999$

$>75000$
Frequency

598
839
1437

1437

388

405

275

369

1437

232

577

628

1437

302

592

541
Percentage

41.6

58.4

100

27

28.2

19.1

25.7

100

16.1

40.2

43.7

100

21.1

41.2

37.7
Mean Claiming Age

(months $>62$ )

39

43

42

42

38

40

35

39

50

31

43

47

Note: Table contains demographics for respondents to Wave 1. Mean claiming ages are based on slightly fewer observations, due to missing claiming ages. Means are weighted

\section{Table 2. Expected Claiming Ages by Frame and Wave}

\begin{tabular}{lrrrrrr} 
Frame & Wave 1.1 & \multicolumn{6}{c}{ Wave 1.2 } & 2ave 2. & Wave 2.2 & Wave 3.1 Wave 3.2 \\
Breakeven & 39.6 & 47.9 & 41.6 & 45.0 & 44.1 & 46.9 \\
66 neutral, c & 54.5 & 57.6 & 58.5 & 60.8 & 61.1 & 64.2 \\
62, gain, c & 58.7 & 65.5 & 60.5 & 65.9 & 60.1 & 64.5 \\
66, gain, c & 62.7 & 63.3 & 61.2 & 64.0 & 59.4 & 64.1 \\
70, loss, c & 57.2 & 57.5 & 56.1 & 55.3 & 62.7 & 52.3 \\
66, loss, c & 65.3 & 61.5 & 57.7 & 63.3 & 53.6 & 59.3 \\
62, gain, i & 58.4 & 63.3 & 57.0 & 67.3 & 57.4 & 64.8 \\
66, gain, i & 63.1 & 62.2 & 60.3 & 65.9 & 66.1 & 60.4 \\
70, loss, i & 57.7 & 57.9 & 54.4 & 57.4 & 53.2 & 52.9 \\
66, loss, i & 62.2 & 61.5 & 59.2 & 61.1 & 61.7 & 57.1
\end{tabular}

Notes: Ages are expressed in months past age 62.

frames; "gain" or "loss" indicate if loss or gain frames were used;

"c" indicates a consumption frame, while "i" indicates an investment fran 
Table 3. Expected Claiming Ages by Frame and Respondent Characteristics

Note: Expressed as number of months after age 62, unweighted data. See Table 2 for additional definitions.

\begin{tabular}{|c|c|c|c|c|c|c|c|c|c|c|c|}
\hline \multicolumn{12}{|l|}{ GEN } \\
\hline Male & 45.7 & 59.9 & 61.1 & 62.8 & 56.2 & 60.3 & 60.7 & 60.5 & 55.1 & 59.3 & 24.4 \\
\hline Female & 42.8 & 58.5 & 63.7 & 62.4 & 56.9 & 60.2 & 61.7 & 64.9 & 55.8 & 61.4 & 40.0 \\
\hline \multicolumn{12}{|l|}{ AGE GROUP } \\
\hline $18-40$ & 44.5 & 63.2 & 63.7 & 67.3 & 63.2 & 64.4 & 62.7 & 68 & 58.8 & 65.4 & 44.9 \\
\hline $41-50$ & 46.1 & 63.1 & 64.5 & 65.3 & 60.4 & 63.5 & 63.6 & 67.2 & 59.4 & 63.3 & 34.7 \\
\hline $51-55$ & 40.4 & 59 & 60.4 & 59.9 & 55.4 & 58 & 62.1 & 62.9 & 53.4 & 58.6 & 42.2 \\
\hline$>55$ & 43.9 & 49.7 & 60.8 & 56.3 & 47.6 & 53 & 56 & 53.3 & 50.1 & 53.6 & 23.2 \\
\hline \multicolumn{12}{|l|}{ EDUCATION } \\
\hline HS or less & 38.5 & 55.4 & 60.2 & 60.6 & 52.7 & 57.8 & 55.9 & 57.9 & 55.6 & 59 & 40.9 \\
\hline \multicolumn{12}{|l|}{ Some college/ } \\
\hline degree & 40.8 & 55.8 & 61.9 & 60 & 56.8 & 59.5 & 61.1 & 59.8 & 51.9 & 57.1 & 39.0 \\
\hline College degree & 48.8 & 63.2 & 64.2 & 65.5 & 58.1 & 61.6 & 63.2 & 67.5 & 58.7 & 64 & 28.0 \\
\hline \multicolumn{12}{|l|}{ HH INCOME } \\
\hline$<35000$ & 44.3 & 58.9 & 63.6 & 60.7 & 56.5 & 58.6 & 59.2 & 62.2 & 57.4 & 60.7 & 28.4 \\
\hline $35000-74999$ & 43.2 & 58.7 & 61.7 & 63 & 56 & 60.6 & 60.9 & 62.2 & 54.1 & 61.2 & 35.6 \\
\hline$>75000$ & 44.9 & 59.6 & 62.9 & 62.9 & 57.3 & 60.6 & 62.6 & 64.3 & 56.1 & 59.6 & 31.6 \\
\hline \multicolumn{12}{|l|}{ OVERALL } \\
\hline Average & 44.1 & 59.1 & 62.6 & 62.5 & 56.6 & 60.2 & 61.3 & 63 & 55.5 & 60.5 & \\
\hline \multicolumn{12}{|l|}{ Standard } \\
\hline Deviation & 31.5 & 29.5 & 28.9 & 30.3 & 29.9 & 31.2 & 28.6 & 30.1 & 30.3 & 30.4 & \\
\hline Frequency & 744 & 736 & 838 & 777 & 754 & 769 & 811 & 807 & 719 & 779 & \\
\hline
\end{tabular}


Table 4. Framing Regressions: Dependent Variable is Expected Claiming Age

Note: Dependent variable is expressed as number of months after age 62, unweighted data. Reference frame is Age 66, neutral (see text). Absolute value of t statistics in parentheses; * significant at 5\%; ** significant at $1 \%$. See Table 2 and text for additional definitions.

\begin{tabular}{|c|c|c|c|c|c|}
\hline FRAME & Wave 1.1 & Wave 1.2 & $\begin{array}{l}\text { Wave } 1.2 \text {, } \\
\text { lagged } \\
\text { dummies } \\
\text { included }\end{array}$ & $\begin{array}{l}\text { All waves, } \\
\text { fixed } \\
\text { effects }\end{array}$ & $\begin{array}{l}\text { All waves, } \\
\text { fixed effects, } \\
\text { lagged dummies } \\
\text { included }\end{array}$ \\
\hline \multirow[t]{2}{*}{ Breakeven } & -14.969 & -9.695 & -10.333 & -15.696 & -15.932 \\
\hline & $(4.29)^{\star \star}$ & $(2.62)^{\star \star}$ & $(2.79)^{\star \star}$ & $(16.03) * *$ & $(16.21)^{* *}$ \\
\hline \multirow[t]{2}{*}{ 62_gain_c } & 4.150 & 7.918 & 8.542 & 1.053 & 1.031 \\
\hline & $(1.19)$ & $(2.26)^{\star}$ & $(2.43)^{*}$ & $(1.12)$ & $(1.09)$ \\
\hline \multirow{2}{*}{ 66_gain_c } & 8.191 & 5.711 & 6.467 & 3.736 & 3.988 \\
\hline & $(2.44)^{*}$ & $(1.60)$ & $(1.82)$ & $(3.88)^{* *}$ & $(4.13)^{* \star}$ \\
\hline \multirow[t]{2}{*}{ 70_loss_c } & 2.674 & -0.074 & 0.581 & 2.740 & 2.920 \\
\hline & $(0.78)$ & $(0.02)$ & $(0.16)$ & $(2.81)^{\star \star}$ & $(2.98)^{\star \star}$ \\
\hline \multirow[t]{2}{*}{ 66_loss_c } & 10.791 & 3.957 & 4.947 & 1.300 & 1.641 \\
\hline & $(3.03)^{* *}$ & $(1.09)$ & $(1.37)$ & $(1.35)$ & $(1.70)$ \\
\hline \multirow[t]{2}{*}{ 62_gain_i } & 3.823 & 5.713 & 6.078 & 0.359 & 0.460 \\
\hline & $(1.11)$ & $(1.63)$ & $(1.73)$ & $(0.38)$ & $(0.48)$ \\
\hline \multirow[t]{2}{*}{ 66_gain_i } & 8.546 & 4.683 & 5.229 & 3.321 & 3.623 \\
\hline & $(2.47)^{\star}$ & $(1.26)$ & $(1.41)$ & $(3.50)^{\star *}$ & $(3.80)^{* *}$ \\
\hline \multirow[t]{2}{*}{$70-$ loss $-i$} & 3.113 & 0.351 & 1.700 & 1.948 & 2.326 \\
\hline & $(0.79)$ & $(0.09)$ & $(0.45)$ & $(1.98)^{*}$ & $(2.35)^{\star}$ \\
\hline \multirow[t]{2}{*}{$66-$ loss-i } & 7.652 & 3.903 & 4.501 & 1.060 & 1.282 \\
\hline & $(2.12)^{*}$ & $(1.04)$ & $(1.20)$ & $(1.10)$ & $(1.33)$ \\
\hline \multirow[t]{2}{*}{ Constant } & 54.540 & 57.557 & 53.121 & 58.643 & 57.903 \\
\hline & $(22.22)^{\star \star}$ & $(22.34)^{\star \star}$ & $(14.18)^{* *}$ & $(85.40)^{\star *}$ & $(81.98)^{* *}$ \\
\hline Observations & 1436 & 1417 & 1417 & 7734 & 7734 \\
\hline R-squared & 0.05 & 0.02 & 0.05 & 0.09 & 0.10 \\
\hline $\begin{array}{l}\mathrm{p} \text { gain at } 62 \\
\text { cons=inv }\end{array}$ & 0.92 & 0.51 & 0.465 & 0.45 & 0.538 \\
\hline $\begin{array}{l}p \text { gain at } 66 \\
\text { cons=inv }\end{array}$ & 0.916 & 0.778 & 0.735 & 0.657 & 0.698 \\
\hline $\begin{array}{l}\mathrm{p} \text { loss at } 70 \\
\text { cons=inv }\end{array}$ & 0.911 & 0.909 & 0.764 & 0.416 & 0.545 \\
\hline $\begin{array}{l}\mathrm{p} \text { loss at } 66 \\
\text { cons=inv }\end{array}$ & 0.395 & 0.988 & 0.904 & 0.801 & 0.708 \\
\hline $\begin{array}{c}p \text { cons at } 66 \\
\text { gain=loss }\end{array}$ & 0.452 & 0.620 & 0.666 & 0.011 & 0.015 \\
\hline $\begin{array}{c}\mathrm{p} \text { inv at } 66 \\
\text { gain=loss }\end{array}$ & 0.804 & 0.839 & 0.849 & 0.016 & 0.013 \\
\hline $\begin{array}{l}p \text { joint } \\
\text { cons=inv }\end{array}$ & 0.944 & 0.971 & 0.944 & 0.827 & 0.903 \\
\hline $\begin{array}{c}p \text { joint } \\
\text { gain=loss }\end{array}$ & 0.969 & 0.884 & 0.862 & 0.010 & $\odot .0 \odot 9$ \\
\hline Number of id & & & & 1665 & 1665 \\
\hline $\begin{array}{c}\text { p previous } \\
\text { dummies zero }\end{array}$ & & & 0.02 & & 0.00 \\
\hline
\end{tabular}


Table 5. Framing contrasts (Fixed Effect Models, All Waves: Dependent Variable is Expected Claiming Age)

Note: Dependent variable measured in number of months after age 62, unweighted data. Reference frame is Age 66, neutral (see text). Absolute value of $t$ statistics in parentheses; * significant at 5\%; ** significant at $1 \%$. See Table 2 for additional definitions.

\begin{tabular}{|l|l|l|}
\hline \multicolumn{2}{|l|}{ Table 5: Framing contrasts, fixed effects, all waves } \\
\hline & All waves & $\begin{array}{l}\text { All waves, lagged } \\
\text { dummies included }\end{array}$ \\
\hline Breakeven & -12.876 & -12.881 \\
\hline & $(10.94)^{\star \star}$ & $(10.90)^{\star \star}$ \\
\hline cons_loss & 1.435 & 1.695 \\
\hline & $(1.59)$ & $(1.87)$ \\
\hline cons_gain & 3.807 & 4.031 \\
\hline & $(4.23)^{\star \star}$ & $(4.47)^{\star \star}$ \\
\hline inv_loss & 0.927 & 1.222 \\
\hline & $(1.03)$ & $(1.35)$ \\
\hline inv_gain & 3.250 & 3.557 \\
\hline & $(3.64)^{\star \star}$ & $(3.98)^{\star \star}$ \\
\hline anchor_62 & -2.822 & -3.070 \\
\hline & $(4.30)^{\star \star}$ & $(4.65)^{\star \star}$ \\
\hline anchor_70 & 1.167 & 1.159 \\
\hline & $(1.70)$ & $(1.67)$ \\
\hline Constant & 58.643 & 57.914 \\
\hline & $(85.41)^{\star \star}$ & $(82.04)^{\star \star}$ \\
\hline Observations & 7734 & 7734 \\
\hline Number of id & 1665 & 1665 \\
\hline R-squared & 0.09 & 0.10 \\
\hline p cons_loss=gain & 0.00 & 0.005 \\
\hline p inv_loss=gain & 0.004 & 0.005 \\
\hline p gain_cons=inv & 0.395 & 0.474 \\
\hline p loss_cons=inv & 0.456 & 0.489 \\
\hline p anchor62=70 & 0.000 & 0.000 \\
\hline p joint gain=loss & 0.002 & 0.002 \\
\hline p joint cons=inv & 0.525 & 0.607 \\
\hline p previous dummies & & 0.00 \\
zero & & \\
\hline
\end{tabular}




\section{Table 6. Fixed Effect Models With Interactions, All Waves: Dependent Variable is Expected Claiming Age}

Note: Dependent variable measured in number of months after age 62, unweighted data. Reference frame is Age 66, neutral (see text). Absolute value of t statistics in parentheses; * significant at 5\%; ** significant at $1 \%$. See Table 2 for additional definitions.

\begin{tabular}{|c|c|c|c|c|}
\hline 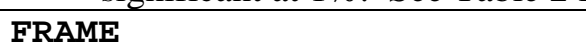 & (1) & $(2)$ & (3) & (4) \\
\hline \multirow{2}{*}{ Breakeven } & -9.633 & -23.383 & -10.681 & -16.790 \\
\hline & $(6.79)^{* *}$ & $(7.60)^{* *}$ & $(7.78)^{\star \star}$ & $(5.70)^{* *}$ \\
\hline \multirow[t]{2}{*}{ LosS_C } & 1.432 & 1.412 & 1.425 & 1.120 \\
\hline & $(1.59)$ & $(1.57)$ & $(1.58)$ & $(1.19)$ \\
\hline \multirow[t]{2}{*}{ Gain_c } & 3.796 & 3.781 & 3.798 & 3.660 \\
\hline & $(4.23)^{\star \star}$ & $(4.21)^{\star \star}$ & $(4.23)^{\star \star}$ & $(3.91)^{\star \star}$ \\
\hline \multirow[t]{2}{*}{ Loss_i } & 0.927 & 0.918 & 0.912 & 0.916 \\
\hline & $(1.03)$ & $(1.02)$ & $(1.01)$ & $(0.97)$ \\
\hline \multirow[t]{2}{*}{ Gain_i } & 3.253 & 3.227 & 3.257 & 3.110 \\
\hline & $(3.65)^{\star \star}$ & $(3.62)^{\star \star}$ & $(3.65)^{\star \star}$ & $(3.33)^{\star *}$ \\
\hline \multirow[t]{2}{*}{ anchor_62 } & -2.808 & -2.807 & -2.831 & -2.837 \\
\hline & $(4.28)^{* *}$ & $(4.28)^{* \star}$ & $(4.32)^{\star \star}$ & $(4.13)^{\star \star}$ \\
\hline \multirow[t]{2}{*}{ anchor_70 } & 1.171 & 1.180 & 1.169 & 1.160 \\
\hline & $(1.71)$ & $(1.72)$ & $(1.71)$ & $(1.62)$ \\
\hline \multirow[t]{2}{*}{ Female* breakeven } & -5.928 & & & \\
\hline & $(4.08)^{\star \star}$ & & & \\
\hline \multirow[t]{2}{*}{ Benefit62* Breakeven } & & 0.008 & & \\
\hline & & $(3.70)^{* *}$ & & \\
\hline \multirow[t]{2}{*}{ Cred. card debt* Breakeven } & & & -4.485 & \\
\hline & & & $(3.10)^{\star \star}$ & \\
\hline \multirow[t]{2}{*}{ Fin. literacy* Breakeven } & & & & 0.055 \\
\hline & & & & $(1.50)$ \\
\hline \multirow[t]{2}{*}{ Constant } & 58.645 & 58.660 & 58.652 & 58.550 \\
\hline & $(85.52)^{* *}$ & $(85.52)^{* *}$ & $(85.48)^{* \star}$ & $(81.57)^{* *}$ \\
\hline Observations & 7734 & 7734 & 7734 & 6994 \\
\hline Number of id & 1665 & 1665 & 1665 & 1445 \\
\hline R-squared & 0.09 & 0.09 & 0.09 & 0.09 \\
\hline
\end{tabular}


Table 7. Fixed Effect Models With Interactions, All Waves: Dependent Variable is Expected Claiming Age

Note: Dependent variable measured in number of months after age 62, unweighted data. Reference frame is Age 66, neutral (see text).Absolute value of $t$ statistics in parentheses; * significant at 5\%; ** significant at $1 \%$. See Table 2 for additional definitions.

\begin{tabular}{|c|c|c|}
\hline & (1) & (2) \\
\hline \multirow[t]{2}{*}{ Breakeven } & -12.876 & -14.072 \\
\hline & $(10.94)^{* *}$ & $(3.28)^{* *}$ \\
\hline \multirow[t]{2}{*}{ Loss_c } & 1.435 & -4.397 \\
\hline & (1.59) & $(1.36)$ \\
\hline \multirow[t]{2}{*}{ Gain_c } & 3.807 & -0.138 \\
\hline & $(4.23)^{* *}$ & $(0.04)$ \\
\hline \multirow[t]{2}{*}{ Loss_i } & 0.927 & -5.194 \\
\hline & (1.03) & $(1.60)$ \\
\hline \multirow[t]{2}{*}{ Gain_i } & 3.250 & -1.695 \\
\hline & $(3.64)^{* *}$ & $(0.52)$ \\
\hline \multirow[t]{2}{*}{ anchor_62 } & -2.822 & -5.863 \\
\hline & $(4.30)^{* *}$ & $(2.42)^{*}$ \\
\hline \multirow[t]{2}{*}{ anchor_70 } & 1.167 & 0.740 \\
\hline & $(1.70)$ & $(0.30)$ \\
\hline \multirow[t]{2}{*}{ Female*Breakeven } & & -5.748 \\
\hline & & $(2.41)^{*}$ \\
\hline \multirow[t]{2}{*}{ Female*Loss_c } & & 0.474 \\
\hline & & $(0.26)$ \\
\hline \multirow[t]{2}{*}{ female*Gain_c } & & -0.525 \\
\hline & & $(0.29)$ \\
\hline \multirow[t]{2}{*}{ female*Loss_i } & & 2.621 \\
\hline & & $(1.43)$ \\
\hline \multirow[t]{2}{*}{ female*Gain_i } & & 0.990 \\
\hline & & $(0.55)$ \\
\hline \multirow[t]{2}{*}{ Female*anchor_66 } & & -0.782 \\
\hline & & (0.58) \\
\hline \multirow[t]{2}{*}{ Female*anchor_70 } & & -0.910 \\
\hline & & $(0.47)$ \\
\hline \multirow[t]{2}{*}{ agecat $2 *$ Breakeven } & & 3.187 \\
\hline & & $(1.04)$ \\
\hline \multirow[t]{2}{*}{ agecat $2 *$ Loss_c } & & -0.311 \\
\hline & & $(0.13)$ \\
\hline \multirow[t]{2}{*}{ agecat $2 *$ Gain_c } & & 0.046 \\
\hline & & $(0.02)$ \\
\hline \multirow[t]{2}{*}{ agecat $2 *$ Loss_i } & & 0.229 \\
\hline & & $(0.09)$ \\
\hline \multirow[t]{2}{*}{ agecat2*Gain_i } & & 0.135 \\
\hline & & $(0.06)$ \\
\hline \multirow[t]{2}{*}{ agecat2*anchor_66 } & & -2.931 \\
\hline & & $(1.70)$ \\
\hline \multirow[t]{2}{*}{ agecat2*anchor_70 } & & -0.582 \\
\hline & & $(0.23)$ \\
\hline \multirow[t]{2}{*}{ agecat3*Breakeven } & & 2.394 \\
\hline & & $(0.70)$ \\
\hline \multirow[t]{2}{*}{ agecat3*Loss_c } & & -0.545 \\
\hline & & $(0.20)$ \\
\hline agecat3*Gain_c & & 0.178 \\
\hline
\end{tabular}




\begin{tabular}{|c|c|c|}
\hline & & $(0.07)$ \\
\hline \multirow{2}{*}{ agecat3*Loss_i } & & -1.243 \\
\hline & & $(0.47)$ \\
\hline \multirow[t]{2}{*}{ agecat3*Gain_i } & & 1.340 \\
\hline & & $(0.53)$ \\
\hline \multirow[t]{2}{*}{ agecat3*anchor_66 } & & -1.582 \\
\hline & & $(0.83)$ \\
\hline \multirow[t]{2}{*}{ agecat3*anchor_70 } & & 1.687 \\
\hline & & $(0.60)$ \\
\hline \multirow[t]{2}{*}{ agecat $4 *$ Breakeven } & & 5.881 \\
\hline & & $(1.81)$ \\
\hline \multirow[t]{2}{*}{ agecat4*Loss_c } & & -1.686 \\
\hline & & $(0.66)$ \\
\hline \multirow[t]{2}{*}{ agecat4*Gain_c } & & 0.977 \\
\hline & & $(0.38)$ \\
\hline \multirow[t]{2}{*}{ agecat $4 *$ Loss_i } & & 1.133 \\
\hline & & $(0.44)$ \\
\hline \multirow[t]{2}{*}{ agecat4*Gain_i } & & -0.748 \\
\hline & & $(0.30)$ \\
\hline \multirow[t]{2}{*}{ agecat4*anchor_66 } & & -2.272 \\
\hline & & $(1.23)$ \\
\hline \multirow[t]{2}{*}{ agecat4*anchor_70 } & & -1.717 \\
\hline & & $(0.65)$ \\
\hline \multirow[t]{2}{*}{ Constant } & 58.643 & 61.715 \\
\hline & $(85.41)^{* *}$ & $(25.55)^{* *}$ \\
\hline Observations & 7734 & 7723 \\
\hline Number of id & 1665 & 1663 \\
\hline R-squared & 0.09 & 0.10 \\
\hline p Loss_c=gain & 0.00 & \\
\hline p Loss_i=gain & 0.004 & \\
\hline p Gain_c=inv & 0.395 & 0.53 \\
\hline p Loss_c $=$ inv & 0.456 & 0.743 \\
\hline p anchor62=70 & 0.000 & \\
\hline p joint gain=loss & 0.002 & 0.275 \\
\hline $\mathrm{p}$ joint cons $=$ inv & 0.525 & 0.777 \\
\hline p income interactions & & 0.674 \\
\hline p education interactions & & 0.122 \\
\hline $\mathrm{p}$ age interactions & & 0.098 \\
\hline p sex interactions & & 0.003 \\
\hline $\mathrm{p}$ anchor66 $=70$ & & 0.056 \\
\hline
\end{tabular}


Figure 1. Average Expected Claiming Ages by Frame

Note: Expressed as number of months after age 62, unweighted.

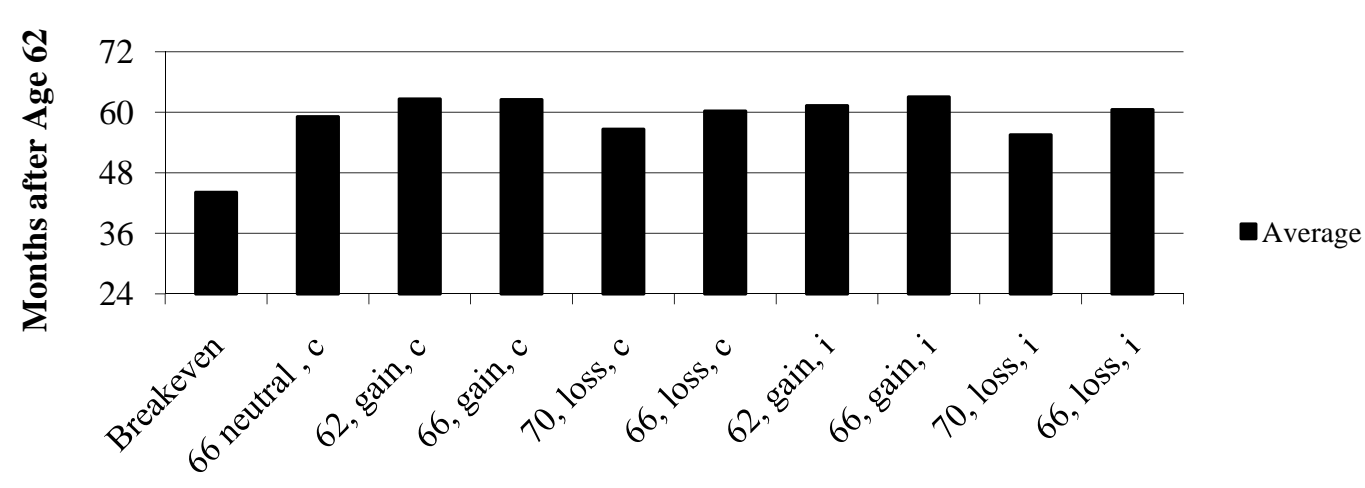

Figure 2. Average Expected Claiming Ages by Frame and Wave Note: Expressed as number of months after age 62, unweighted.
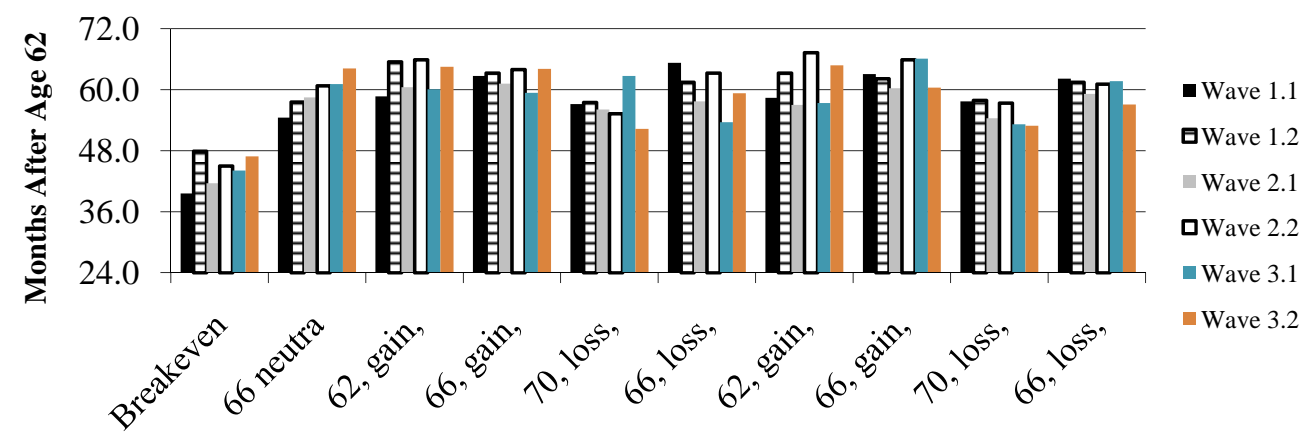

- Wave 3.2 
Figure 3. Expected Claiming Ages by Frame and Respondent Sex Note: Expressed as number of months after age 62, unweighted.

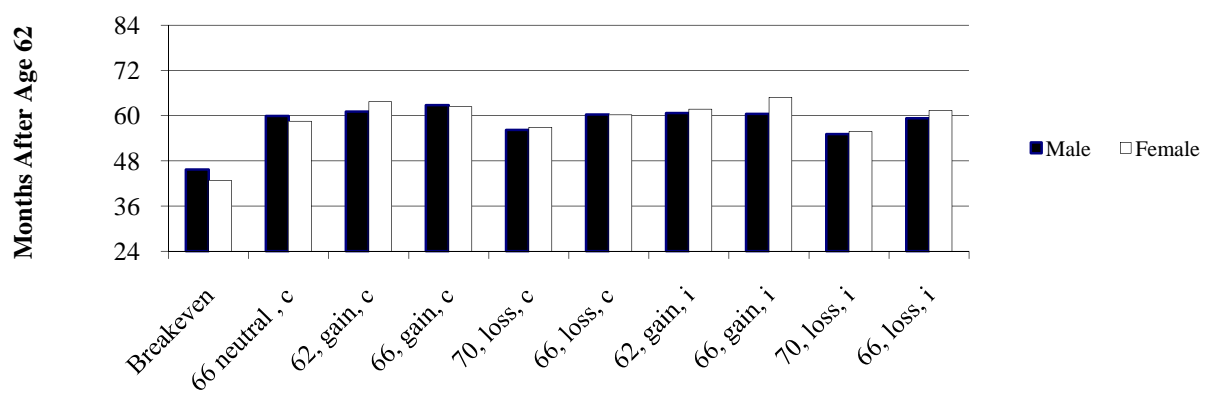

Figure 4. Expected Claiming Ages by Frame and Respondent Age Note: Expressed as number of months after age 62, unweighted.

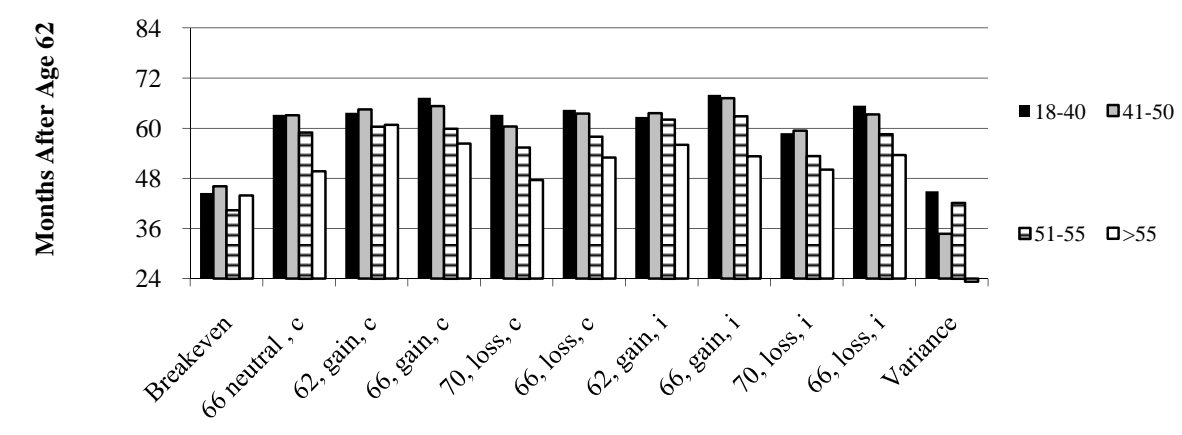


Figure 5. Expected Claiming Ages by Frame and Education (unweighted) Note: Expressed as number of months after age 62, unweighted.

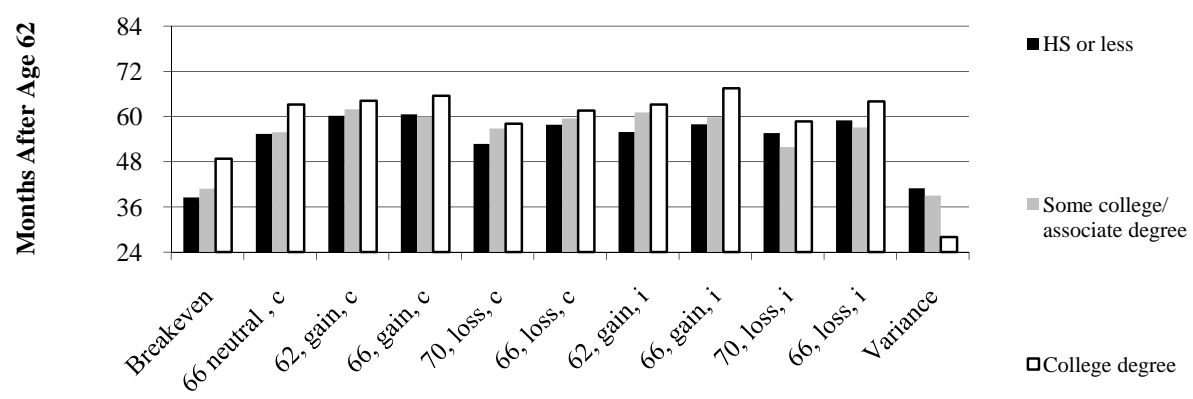

Figure 6. Expected Claiming Ages by Frame and Respondent Income (\$) Note: Expressed as number of months after age 62, unweighted.

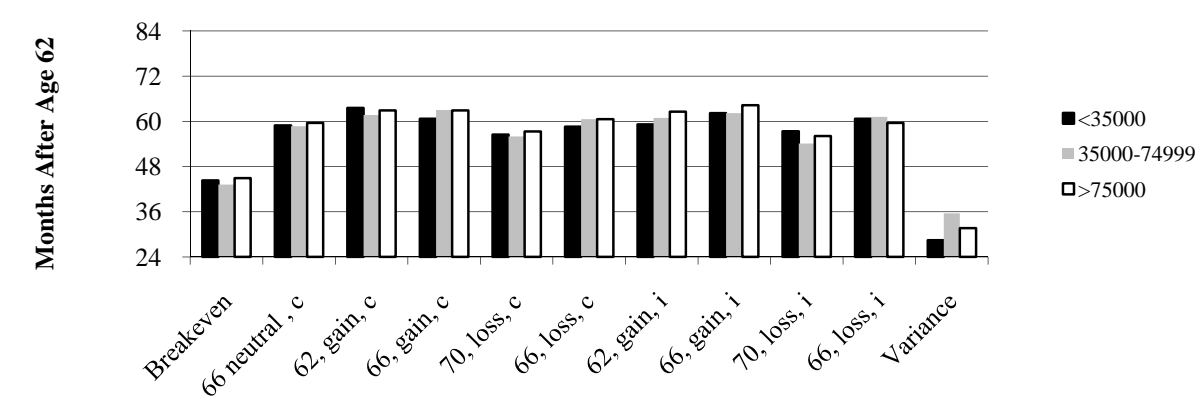




\section{Appendix A: The Ten Frames}

Frame 1: Baseline (Neutral)

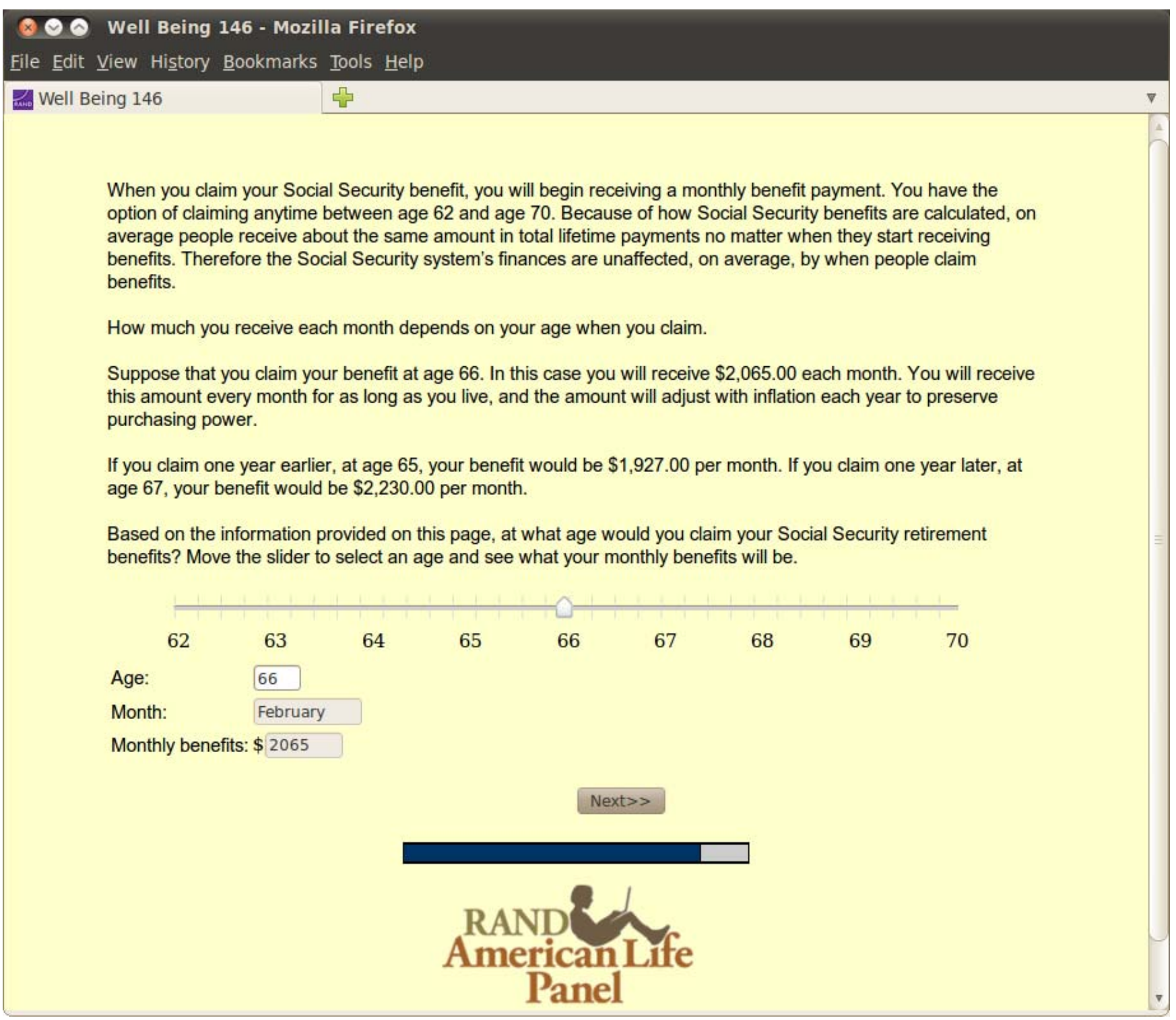


Frame 2: Breakeven

QQ Well Being 146 - Mozilla Firefox

File É Edit View Hiștory Bookmarks Iools Help

Well Being 146

When you claim your Social Security benefit, you will begin receiving a monthly benefit payment. Because of how Social Security benefits are calculated, on average people receive about the same amount in total lifetime payments no matter when they start receiving benefits. Therefore the Social Security system's finances are unaffected, on average, by when people claim benefits.

How much you receive each month depends on your age when you claim

Suppose that you claim your benefit at age 62 . In this case you will receive $\$ 1,549.00$ each month. You will receive this amount every month for as long as you live, and the amount of the payment will adjust with inflation each year to preserve purchasing power.

If you delay claiming, your monthly benefit will increase. For example, if you claim your benefits at age 63 (one year later), your benefit will increase by $\$ 103.00$ per month to $\$ 1,652.00$. However, by delaying your benefit by one year, you will forfeit the $\$ 18,588.00$ that you would have received between age 62 and 63 . By our calculations, you would need to live at least 15 more years in order to get back the $\$ 18,588.00$ you forfeited by waiting one year.

Based on the information provided on this page, at what age would you claim your Social Security retirement benefits? Move the slider to select an age and see what your monthly benefits will be.

\begin{tabular}{lllllllll}
\hline 62 & 63 & 64 & 65 & 66 & 67 & 68 & 69 & 70
\end{tabular}

Age:

62

Month:

Monthly benefits: $\$ 1549$

Monthly increase relative to claiming at age 62: \$1549

Total amount forfeited by not claiming at age 62 : $\$ 0$

Number of years required to break-even: 
Frame 3: 62, gain, consumption

\section{Q๑ Well Being 146 - Mozilla Firefox}

File Edit View History Bookmarks Iools Help

\section{맴 Well Being 146}

$$
\text { ऍ }
$$

When you claim your Social Security benefit, you will begin receiving a monthly benefit payment. This benefit

provides a base level of income that you can count on to help pay your bills for as long as you live. Because of how Social Security benefits are calculated, on average people receive about the same amount in total lifetime payments no matter when they start receiving benefits. Therefore the Social Security system's finances are unaffected, on average, by when people claim benefits.

How much you receive each month depends on your age when you claim

By claiming at an older age, you increase the purchasing power from your Social Security benefit each month, and you gain extra protection against outliving your resources since you will have more money to live on each month for the rest of your life. Because the amount will adjust each year with inflation, you will maintain the same purchasing power for the rest of your life. This can be important if you live beyond your life expectancy.

The earliest that you can claim Social Security retirement benefits is at age 62, but you get a lower benefit at that age. At age 62 you will receive $\$ 1,549.00$ from Social Security to spend each month. If you claim later than this - as late as age 70 -you will be able to buy more with your Social Security benefit each month.

For example, if you start your benefit at age 63 (one year later), your purchasing power goes up an extra $\$ 103.00$ per month to $\$ 1,652.00$. If you start your benefit at age 70 , the amount you can spend each month goes up by $\$ 1,177.00$ to $\$ 2,726.00$.

The larger monthly benefits are permanent, so you will always have more money to spend each month for the rest of your life.

Based on the information provided on this page, at what age would you claim your Social Security retirement benefits? Move the slider to select an age and see what your monthly benefits will be.

63

64

65

66

67

68

Age:

Month:

62

Monthly benefits: \$1549

How much you get more per month than when you claim at $62: \$ 0$ 
Frame 4: 66, gain, consumption

Q๑ Well Being 146 - Mozilla Firefox

File Edit View History Bookmarks Iools Help

Well Being 146 乌

When you claim your Social Security benefit, you will begin receiving a monthly benefit payment. This benefit provides a base level of income that you can count on to help pay your bills for as long as you live. Because of how Social Security benefits are calculated, on average people receive about the same amount in total lifetime payments no matter when they start receiving benefits. Therefore the Social Security system's finances are unaffected, on average, by when people claim benefits.

How much you receive each month depends on your age when you claim.

By claiming at an older age, you increase the purchasing power from your Social Security benefit each month, and you gain extra protection against outliving your resources since you will have more money to live on each month for the rest of your life. Because the amount will adjust each year with inflation, you will maintain the same purchasing power for the rest of your life. This can be important if you live beyond your life expectancy.

The earliest that you can claim Social Security retirement benefits is at age 62, but Social Security's 'normal retirement age' is age 66 . At age 66 you will receive $\$ 2,065.00$ from Social Security to spend each month. If you claim later than this - as late as age 70 - you will be able to buy more with your Social Security benefit each month.

For example, if you start your benefit at age 67 (one year later than the normal retirement age), your purchasing power goes up an extra $\$ 165.00$ per month to $\$ 2,230.00$. If you start your benefit at age 70 , the amount you can spend each month goes up by $\$ 661.00$ to $\$ 2,726.00$.

The larger monthly benefits are permanent, so you will always have more money to spend each month for the rest of your life.

Based on the information provided on this page, at what age would you claim your Social Security retirement benefits? Move the slider to select an age and see what your monthly benefits will be.

\begin{tabular}{lllllllll}
\hline 62 & 63 & 64 & 65 & 66 & 67 & 68 & 69 & 70
\end{tabular}

Age:

66

Month:

Monthly benefits: $\$ 2065$

How much you get more per month than when you claim at $66: \$ 0$ 
Frame 5: 70, loss, consumption

\section{$\otimes \odot$ Well Being 146 - Mozilla Firefox}

File Edit View History Bookmarks Iools Help

Well Being 146

$$
\text { ऍ }
$$

When you claim your Social Security benefit, you will begin receiving a monthly benefit payment. This benefit provides a base level of income that you can count on to help meet your monthly expenses for as long as you live. Because of how Social Security benefits are calculated, on average people receive about the same amount in total lifetime payments no matter when they start receiving benefits. Therefore the Social Security system's finances are unaffected, on average, by when people claim benefits.

How much you receive each month depends on your age when you claim.

By claiming at a younger age, you reduce the purchasing power from your Social Security benefit each month, and you will have less protection against outliving your resources since you will have less money to live on each month for the rest of your life. Because the amount will adjust each year with inflation, you will maintain the same purchasing power for the rest of your life. This can be important if you live beyond your life expectancy.

The highest amount you can get from Social Security benefits is to wait until age 70 to claim benefits. At age 70 , you will receive $\$ 2,726.00$ from Social Security to spend each month. If you claim earlier than this - as early as age 62 - the amount of purchasing power you will get from your Social Security benefit will be less.

For example, if you start your benefit at age 69 (one year earlier), the amount you can spend each month falls $\$ 165.00$ to only $\$ 2,561.00$. If you start your benefit at age 62 , the amount you can spend each month from Social Security falls $\$ 1,177.00$ to only $\$ 1,549.00$.

These monthly benefit cuts are permanent, so you will always have less to spend each month for the rest of your life.

Based on the information provided on this page, at what age would you claim your Social Security retirement benefits? Move the slider to select an age and see what your monthly benefits will be.

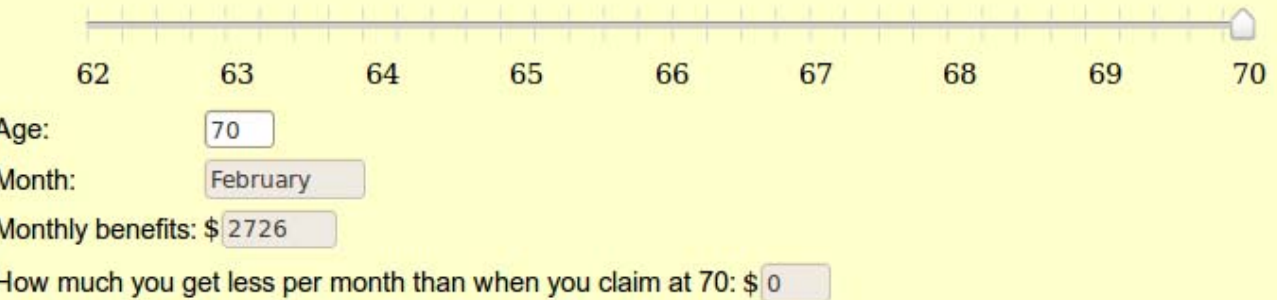


Frame 6: 66, loss, consumption

\section{QQ Well Being 146 - Mozilla Firefox}

File É Edit View Hiștory Bookmarks Iools $\underline{\text { Help }}$

When you claim your Social Security benefit, you will begin receiving a monthly benefit payment. This benefit provides a base level of income that you can count on to help meet your monthly expenses for as long as you live. Because of how Social Security benefits are calculated, on average people receive about the same amount in total lifetime payments no matter when they start receiving benefits. Therefore the Social Security system's finances are unaffected, on average, by when people claim benefits.

How much you receive each month depends on your age when you claim.

By claiming at a younger age, you reduce the purchasing power from your Social Security benefit each month, and you will have less protection against outliving your resources since you will have less money to live on each month for the rest of your life. Because the amount will adjust each year with inflation, you will maintain the same purchasing power for the rest of your life. This can be important if you live beyond your life expectancy.

The latest you can claim Social Security benefits is age 70, but Social Security's 'normal retirement age' is age 66. At age 66 , you will receive $\$ 2,065.00$ from Social Security to spend each month. If you claim earlier than this - as early as age 62 - the amount of purchasing power you will get from your Social Security benefit will be less.

For example, if you start your benefit at age 65 (one year earlier than the normal retirement age), the amount you can spend each month falls $\$ 165.00$ to only $\$ 2,230.00$. If you start your benefit at age 62 , the amount you can spend each month from Social Security falls by $\$ 516.00$ to only $\$ 1,549.00$.

These monthly benefit cuts are permanent, so you will always have less to spend each month for the rest of your

Based on the information provided on this page, at what age would you claim your Social Security retirement benefits? Move the slider to select an age and see what your monthly benefits will be.

64

65

66

67

Age:

Month:

February

Monthly benefits: \$2065

How much you get more per month than when you claim at 66 : $\$ 0$ 
Frame 7: 62, gain, investment

QQ Well Being 146 - Mozilla Firefox

File Edit View History Bookmarks Iools Help

Well Being 146

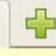

When you claim your Social Security benefit, you will begin receiving a monthly benefit payment. These payments represent the return you get on the contributions you made in the Social Security system while you were working. Because of how Social Security benefits are calculated, on average people receive about the same amount in total lifetime payments no matter when they start receiving benefits. Therefore the Social Security system's finances are unaffected, on average, by when people claim benefits.

How much you receive each month depends on your age when you claim.

By claiming at older ages, you raise the monthly return on your contributions.

For example, suppose that you claim your benefit at age 62, which is the earliest you can claim Social Security retirement benefits. In this case, based on your contributions, Social Security will return $\$ 1,549.00$ to you each month. You will receive a benefit every month after you turn age 62 for as long as you live, and the amount will adjust with inflation each year to preserve the purchasing power of this return. If you claim later than this - as late as age 70 - the amount that Social Security will return to you as a retirement benefit will be larger.

For example, if you start your benefit at age 63 (one year later), the amount you get back from Social Security goes up an extra $\$ 103.00$ per month to $\$ 1,652.00$. If you start your benefit at age 70 , the amount returned to you goes up by $\$ 1,177.00$ to $\$ 2,726.00$ per month.

The larger monthly returns on your contributions are permanent, and these larger returns will be adjusted for inflation, enabling them to retain their higher purchasing power. So you will have more money returned to you each month for the rest of your life.

Based on the information provided on this page, at what age would you claim your Social Security retirement benefits? Move the slider to select an age and see what your monthly benefits will be.

\begin{tabular}{lllllllll}
\hline 62 & 63 & 64 & 65 & 66 & 67 & 68 & 69 & 70
\end{tabular}

Age:

62

Month:

Monthly benefits: $\$ 1549$

How much you get more per month than when you claim at 62: \$0 
Frame 8: 66, gain, investment

Q $\odot$ Well Being 146 - Mozilla Firefox

File Edit View History Bookmarks Iools Help

Well Being 146

\section{p}

When you claim your Social Security benefit, you will begin receiving a monthly benefit payment. These payments represent the return you get on the contributions you made in the Social Security system while you were working. Because of how Social Security benefits are calculated, on average people receive about the same amount in total lifetime payments no matter when they start receiving benefits. Therefore the Social Security system's finances are unaffected, on average, by when people claim benefits.

How much you receive each month depends on your age when you claim.

By claiming at older ages, you raise the monthly return on your contributions.

The earliest you can claim Social Security retirement benefits is age 62, but Social Security's "normal retirement age" is age 66. If you claim at 66, based on your contributions, Social Security will return $\$ 2,065.00$ to you each month. You will receive a benefit every month after you turn age 66 for as long as you live, and the amount will adjust with inflation each year to preserve the purchasing power of this return. If you claim later than this - as late as age 70 - the amount that Social Security will return to you as a retirement benefit will be larger.

For example, if you start your benefit at age 67 (one year later than the normal retirement age), the amount you get back from Social Security goes up an extra $\$ 165.00$ per month to $\$ 2,230.00$. If you start your benefit at age 70 , the amount returned to you goes up by $\$ 661.00$ to $\$ 2,726.00$ per month.

The larger monthly returns on your contributions are permanent, and these larger returns will be adjusted for inflation, enabling them to retain their higher purchasing power. So you will have more money returned to you each month for the rest of your life.

Based on the information provided on this page, at what age would you claim your Social Security retirement benefits? Move the slider to select an age and see what your monthly benefits will be.

\begin{tabular}{lllllllll}
\hline 62 & 63 & 64 & 65 & 66 & 67 & 68 & 69 & 70
\end{tabular}

Age:
Month:
Monthly benefits: $\$ 2065$
How much you get more per month than when you claim at $66: \$ 0$


Frame 9: 70, loss, investment

Q๑ Well Being 146 - Mozilla Firefox

File Edit View History Bookmarks Iools Help

Well Being 146

둡

When you claim your Social Security benefit, you will begin receiving a monthly benefit payment. These payments represent the return you get on the contributions you made in the Social Security system while you were working. Because of how Social Security benefits are calculated, on average people receive about the same amount in total lifetime payments no matter when they start receiving benefits. Therefore the Social Security system's finances are unaffected, on average, by when people claim benefits.

How much you receive each month depends on your age when you claim.

By claiming at younger ages, you reduce the monthly return on your contributions.

For example, suppose that you claim your benefit at age 70 , which is the age at which you get the highest return. In this case, based on your contributions, Social Security will return $\$ 2,726.00$ to you each month. You will receive a payment every month after you turn age 70 for as long as you live, and the amount will adjust with inflation each year to preserve the purchasing power of this return. If you claim earlier than this - as early as age 62 - your Social Security return will be cut.

For example, if you start your benefit at age 69 (one year earlier), the amount you get back from Social Security falls $\$ 165.00$ per month to only $\$ 2,561.00$. If you start your benefit at age 62 , the amount you get returned to you falls by $\$ 1,177.00$ to only $\$ 1,549.00$ per month.

The reduced return on your contributions is permanent, so you will have less money returned to you each month for the rest of your life.

Based on the information provided on this page, at what age would you claim your Social Security retirement benefits? Move the slider to select an age and see what your monthly benefits will be.

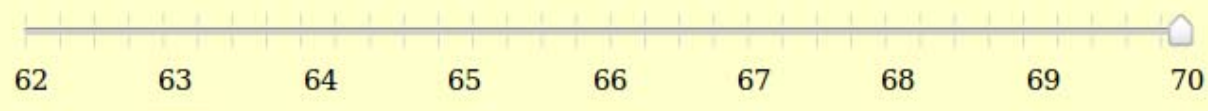

Age:

70

Month:

February

Monthly benefits: $\$ 2726$

How much you get less per month than when you claim at $70: \$ 0$ 
Frame 10: 66, loss, investment

\section{Q๑ Well Being 146 - Mozilla Firefox}

File Edit View History Bookmarks Iools Help

Well Being 146

ऍ

When you claim your Social Security benefit, you will begin receiving a monthly benefit payment. These payments represent the return you get on the contributions you made in the Social Security system while you were working. Because of how Social Security benefits are calculated, on average people receive about the same amount in total lifetime payments no matter when they start receiving benefits. Therefore the Social Security system's finances are unaffected, on average, by when people claim benefits.

How much you receive each month depends on your age when you claim.

By claiming at younger ages, you reduce the monthly return on your contributions.

The latest you can claim Social Security benefits is age 70, but Social Security's "normal retirement age" is age 66. If you claim at 66 , based on your contributions, Social Security will return $\$ 2,065.00$ to you each month. You will receive a payment every month after you turn age 66 for as long as you live, and the amount will adjust with inflation each year to preserve the purchasing power of this return. If you claim earlier than this - as early as age 62 - your Social Security return will be cut.

For example, if you start your benefit at age 65 (one year earlier than the normal retirement age), the amount you get back from Social Security falls by $\$ 165.00$ per month to only $\$ 2,230.00$. If you start your benefit at age 62 , the amount you get returned to you falls by $\$ 516.00$ to only $\$ 1,549.00$ per month.

The reduced return on your contributions is permanent, so you will have less money returned to you each month for the rest of your life.

Based on the information provided on this page, at what age would you claim your Social Security retirement benefits? Move the slider to select an age and see what your monthly benefits will be.

62

63

64

65

66

67

68

69

70

Age:

Month:

Monthly benefits: $\$ 2065$

How much you get more per month than when you claim at $66: \$ 0$ 